\title{
Rochas charnockíticas do sudeste de Minas Gerais: a raiz granulítica do arco magmático do Orógeno Araçuaí
}

\author{
Tiago Amâncio Novo ${ }^{1,2}$, Antônio Carlos Pedrosa Soares ${ }^{2}$, Carlos Mauricio Noce ${ }^{2}$, \\ Fernando Flecha de Alkmim ${ }^{3}$ \& Ivo Antônio Dussin ${ }^{4}$
}

\begin{abstract}
Resumo Os orógenos Araçuaí e Ribeira constituem sistema orogênico neoproterozóico-cambriano que se estende da borda oriental do Cráton do São Francisco até o Oceano Attântico, a sul do paralelo $15^{\circ}$. A zona de fronteira entre esses orógenos situa-se em torno do paralelo $21^{\circ}$. A região meridional do Orógeno Araçuaí, no sudeste de Minas Gerais, é caracterizada pela exposição de rochas metamórficas de alto grau, ortoderivadas e paraderivadas, refletindo o profundo nível crustal ali exposto. Uma associação de rochas charnockíticas máficas a félsicas, metamorfisadas na fácies granulito, recebeu a designação de Suíte Divino. Esta tem características de série cálcio-alcalina expandida, metaluminosa a ligeiramente peraluminosa, com padrão de elementos traços característico de magmatismo de arco de margem continental. A assinatura isotópica de $\mathrm{Nd}$ evidencia significativo envolvimento de fusões derivadas do embasamento paleoproterozóico. Datações U-Pb (LA-ICPMS) de rochas da Suíte Divino (592 \pm 7 Ma e 603 $\pm 4 \mathrm{Ma}$ ) indicam idade compatível com o estágio pré-colisional (acrescionário) do orógeno. Desta forma, sugere-se que a Suíte Divino representa a raiz granulítica do arco magmático do Orógeno Araçuaí, cuja eventual continuidade para sul seria importante elo de ligação com o Orógeno Ribeira.
\end{abstract}

Palavras-chave: charnockito, arco magmático, Orógeno Araçuaí.

\begin{abstract}
Charnockites from southearstern Minas Gerais: the magmatic arc granulitic roots of the Araçuai Orogen. The Araçuaí and Ribeira orogens are a Cambrian-Neoproterozoic belt that extends from the eastern edge of the San Francisco craton to the Atlantic Ocean, south of parallel $15^{\circ}$. The connection between these orogens is roughly situated along the $21^{\circ} \mathrm{S}$ parallel. High-grade metamorphic rocks are exposed in the southern Araçuaí Belt, SE Minas Gerais, reflecting a deep crustal level. The Divino Suite comprises mafic- to felsisc charnockites, metamorphosed in granulite facies, interpreted as an expanded calc-alkaline suite metaluminous to slightly peraluminous. Chemical and Nd isotopic signatures suggest the Divino Suite evolved in a continental magmatic-arc setting, and also that Paleoproterozoic basement was a major source for parental magmas. $\mathrm{U}-\mathrm{Pb}$ dating of charnockite samples $(592 \pm 7$, and $603 \pm 4 \mathrm{Ma}$ ) indicates the suite is coeval with the pre-collisional stage of Araçuaí Orogen evolution, and probably represents the magmatic arc granulitic roots. The southward extent of this arc is of great importance in order to unveil the link between Araçuaí and Ribeira orogens.
\end{abstract}

Keywords: charnockite, magmatic arc, Araçuaí Orogen

INTRODUÇÃo O Orógeno Araçuaí e o Orógeno Ribeira setentrional constituem sistema orogênico Neoproterozóico-Cambriano que se estende da borda oriental do Cráton São Francisco até o Oceano Atlântico, a sul do paralelo $15^{\circ}$. A zona limite entre esses orógenos situa-se em torno do paralelo $21^{\circ} \mathrm{S}$, balizada pela extremidade meridional do Cráton São Francisco (PedrosaSoares et al. 2001). A região estudada, no sudeste do Estado de Minas Gerais e extremo noroeste do Estado do Rio de Janeiro, está situada nesta zona limite entre os dois orógenos. O substrato geológico é definido pela intercalação tectônica de escamas constituídas por ortognaisses granulíticos paleoproterozóicos do Complexo Juiz de Fora, e por rochas supracrustais, essencialmente paragnaisses. Nesta região, o limite entre os orógenos Araçuaí e Ribeira não é marcado por descontinuidade estrutural ou das unidades litológicas e, portanto, deve ser entendido como zona de conexão entre setores distintos de um mesmo sistema orogênico. Para a reconstituição geotectônica desta conexão, e dos orógenos como um todo, o(s) arco(s) magmático(s) são peça chave. No presente trabalho é descrita suíte plutônica constituída por granitóides charnockíticos, designada Suíte Divino, intrusiva no substrato formado pela associação gnaisse Juiz de Fora/paragnaisse. Uma das hipóteses assumidas a cerca destas rochas é que representem a continuação, em crosta profunda, do arco magmático do Orógeno Araçuaí. A outra hipótese é que teriam sido geradas durante a etapa sincolisional da Orogenia Brasiliana, sendo produto da anatexia de ortognaisses do Complexo Juiz de Fora e/ou outras unidades regionais. Para responder a estas questões procedeu-se, além do mapeamento e

1 - Programa de Pós-graduação, IGC-UFMG, Campus Pampulha, Belo Horizonte (MG), Brasil. E-mail: tiagoanovo@gmail.com

2 - CPMTC-IGC-UFMG, Campus Pampulha, Belo Horizonte (MG), Brasil. E-mail: pedrosa@pesquisador.cnpq.br; noce@igc.ufmg.br

3 - UFOP, Depto de Geologia, Morro do Cruzeiro, Ouro Preto (MG), Brasil. E-mail: alkmim@degeo.ufop.br

4 - UFRGS, IG, Departamento de Geologia, Porto Alegre (RS), Brasil. E-mail: ivodusin@yahoo.com.br 
caracterização geológicas, ao estudo geoquímico, isotópico e à datação da Suíte Divino.

Este trabalho apresenta resultados decorrentes do mapeamento da folha Carangola, em escala 1:100.000 (SF-23-X-B-VI - situada entre os paralelos 20 $30^{\circ}$ $21^{\circ} 00^{\prime} \mathrm{S}$ e meridianos $42^{\circ} 00-42^{\circ} 15^{\prime} \mathrm{W}$ ), do Programa Geologia do Brasil - Contrato CPRM-UFMG, complementados por estudos e análises custeadas por projetos de pesquisa financiados pelo CNPq e FAPEMIG.

Utilizam-se os termos pré-colisional e sincolisional com conotação geotectônica, para relacionar os episódios magmáticos aos estágios de evolução orogênicos (evitando termos dúbios como pré, sin e pós-tectônico).

GEOLOGIA REGIONAL O sistema orogênico brasiliano-panafricano do Paleocontinente Gondwana representa um conjunto de orógenos neoproterozóicos diacrônicos, do qual faz parte a Província Mantiqueira (Brito-Neves et al. 1999, Almeida et al. 1981, 2000, Heilbron et al. 2004, Silva et al. 2005). Geograficamente, a província está compreendida na porção sul-oriental do Continente Sul-Americano, estendendo-se do sul da Bahia até o Uruguai. A região abordada está inserida no segmento setentrional da Província Mantiqueira (Heilbron et al. 2004), na zona da conexão entre os orógenos Araçuaí e Ribeira (Fig. 1a). Existem discrepâncias em relação aos modelos de evolução geotectônica mais amplamente aceitos para cada orógeno, resultando no fato do posicionamento paleotectônico desta região variar de acordo com a linha de abordagem. Em termos da compartimentação tectono-estratigráfica do Orógeno Ribeira, a área estudada situa-se no Domínio Juiz de Fora do Terreno Ocidental, que engloba o embasamento paleoproterozóico, a cobertura neoproterozóica e granitóides, e integra a placa inferior (lower plate) do orógeno (Heilbron \& Machado, 2003). Por sua vez, de acordo com a compartimentação do Orógeno Araçuaí, a região encontra-se no domínio orogênico interno onde se situam o arco magmático pré-colisional e bacias relacionadas (Pedrosa Soares et al. 2001).

Em termos estruturais a região encontra-se no domínio de extensas zonas de cisalhamento destrais, especificamente aquelas de Abre Campo e Manhuaçu (Cunningham et al. 1998, Peres et al. 2004, Noce et al. 2006). A Falha de Abre Campo marca o limite ocidental entre o terreno representado pelos plutonitos da Suíte Divino e suas rochas encaixantes (Complexo Juiz de Fora e unidade de paragnaisses), e as rochas do Complexo Mantiqueira (Fig. 1b). Este último, também de idade paleoproterozóica à semelhança do Complexo Juiz de Fora (Noce et al. 2007b), é composto por ortognaisses bandados e migmatitos da fácies anfibolito. Cunningham et al. (1998) interpretaram a Falha de Abre Campo como uma possível zona de sutura brasiliana.

A SUÍTE DIVINO Os granitóides charnockíticos da Suíte Divino afloram como corpos alongados na direção NNE-SSW, de dimensões muito variadas, em geral com poucos quilômetros de extensão. O maior corpo está exposto na região de Muriaé, atingindo extensão superior a $50 \mathrm{~km}$. Estão encaixados tanto nas rochas do Complexo Juiz de Fora como nos paragnaisses da cobertura metassedimentar (Grupo Andrelândia), ou ao longo do contato entre estas duas unidades (Fig. 1b).

A designação Suíte Divino decorre da ocorrência, nos arredores da cidade homônima, de uma exposição característica desta unidade (UTM 795441E/7716977N). O esquema de Frost \& Frost (2008) para a classificação de rochas charnockíticas foi adotado neste trabalho, evitando-se a utilização de termos como enderbito, jotunito, opdalito e manjerito. Usa-se o termo charnockíto acompanhado do adjetivo apropriado de acordo com a classificação para rochas ígneas da IUGS. Deste modo, um termo como "opdalito" é substituído por "charnockíto granodiorítico", "enderbito" por "charnockito tonalítico", etc.

Caracterização Petrográfica As rochas charnockíticas da Suíte Divino (Fig. 2) possuem cor esverdeada e ampla variação composicional e granulométrica. A granulação varia de fina a grossa, enquanto a composição posiciona-se entre granítica, granodiorítica, tonalítica e diorítica. Granulação e composição não são correlacionáveis, ou seja, independentemente de sua composição a rocha pode apresentar grão fino, médio ou grosso.

A composição mineralógica dos granitóides charnockíticos é dada por proporções variáveis de quartzo, plagioclásio, feldspato potássico, hornblenda, hiperstênio e clinopiroxênio (Fig. 2b). A textura varia de granoblástica a, subordinadamente, nematoblástica. Hiperstênio é o piroxênio mais freqüente. Ambos os piroxênios (orto e clinopiroxênio) apresentam intensidade de alteração variável, de moderada a alta. $\mathrm{O}$ feldspato potássico apresenta-se parcialmente alterado, com formação de sericita. Plagioclásio encontra-se moderadamente saussuritizado (carbonato e sericita são os principais produtos desta alteração, epidoto ocorre de forma subordinada), apresenta geminação polissintética e raro intercrescimento antipertítico. Localmente, observa-se a cristalização de quartzo vermiforme no contato entre os feldspatos. Quartzo sempre apresenta extinção ondulante e outras feições de recristalização metamórfica, tais como quartzo fitado e subgranulação. Tanto hornblenda quanto biotita derivam da alteração dos piroxênios. Hornblenda possui cor marrom, indicando enriquecimento em titânio (confirmado pela associação com titanita).

A mineralogia acessória consiste em apatita, zircão, opacos, titanita e granada. Apatita tem granulação fina e é o mineral acessório mais comum, sendo observado em todas as amostras, ocorrendo em cristais com o típico habito hexagonal-arredondado. Zircão ocorre em cristais prismáticos curtos e em grãos arredondados. Os minerais opacos descritos são ilmenita e hematita, que ocorrem como cristais anédricos de granulação fina a média. Comumente, os minerais opacos apresentamse associados aos piroxênios, como produto de alteração destes. Granada é rara a ausente.

O desenvolvimento da foliação é irregular; as rochas apresentam frequentemente aspecto maciço (Fig. 2a), mas a foliação regional tende a se destacar em aflo- 


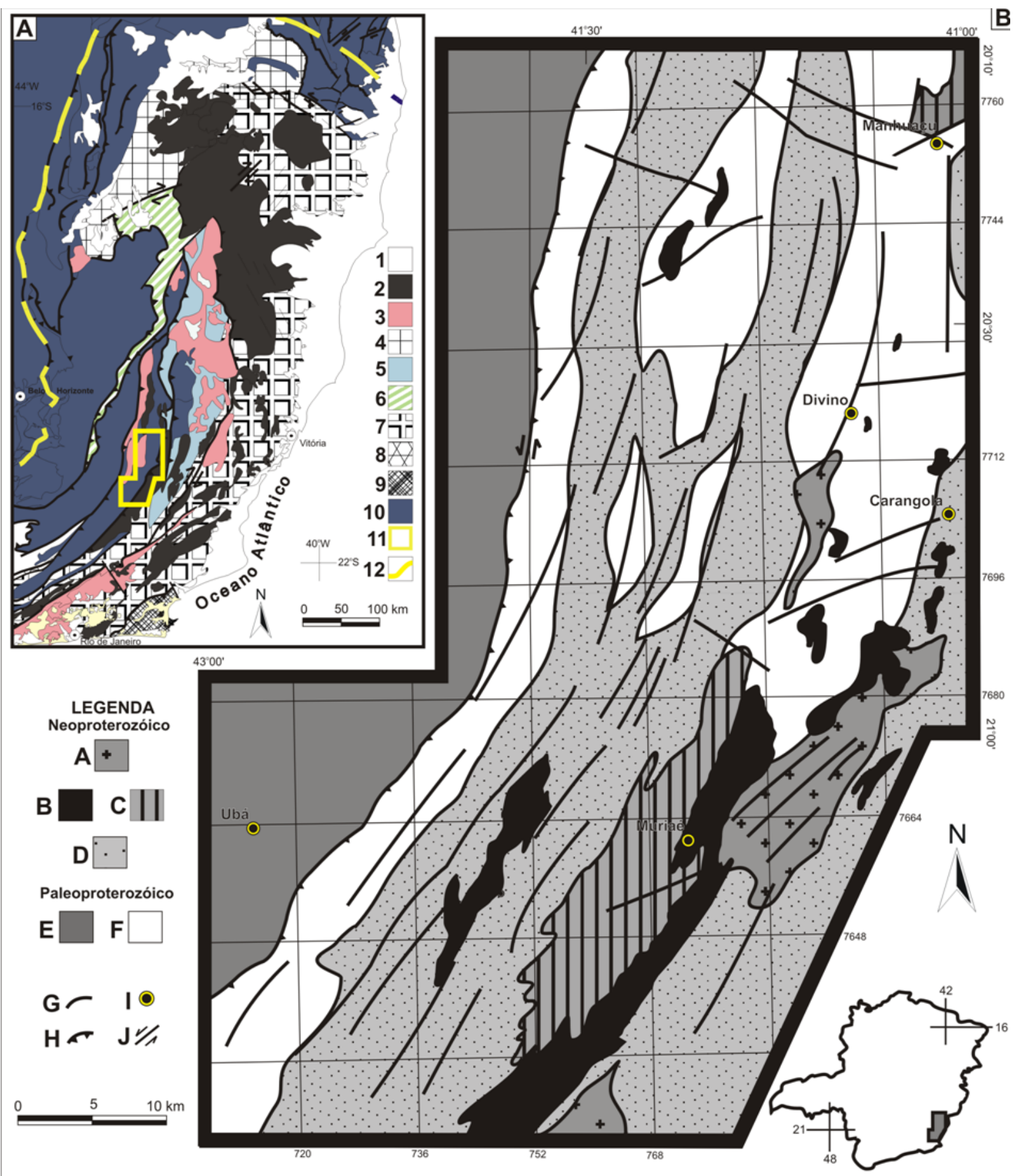

Figura 1 - (A) Localização da área de estudo na Província Mantiqueira Setentrional (extraído de Silva et al. 2005). Legenda: 1) Coberturas e rochas magmáticas fanerozóicas; 2) Granitóides pós (tipo I e S) a sin-colisionais (tipo S); 3) Granitóides pré-colisionais e pré-sin-colisionais; 4) Formação Salinas - Depósitos marinhos tardi-colisionais de águas profundas (fácies xisto verde); 5) Grupo Rio Doce - unidades vulcano-sedimentares pré-colisionais relacionadas ao arco (fácies anfibolito); 6) Formação Ribeirão da Folha e Grupo Dom Silvério - depósitos vulcano-sedimentares de águas profundas, com remanescentes de assoalho oceânico (fácies anfibolito); 7) Complexos paragnáissicos, fácies anfibolito/granulito, parcialmente migmatizados; 8) Terreno Embu, Ortognaisses tonalíticos; granitóides e paragnaisse; embasamento do Grupo Serra de Itaberaba; Sequência metavulcano-sedimentar (bacia de retro-arco); 9) Orógeno Búzios, Sequência metavulcano-sedimentar de retro-arco; ortognaisses orosirianos de embasamento (Terreno Cabo Frio); 10) Embasamento e unidades pré Neoproterozóico; 11) Localização da área de estudo; 12) Limite do Cráton São Francisco. (B) Mapa geológico da área de estudo, leste de Minas Gerais. Legenda: A) Suite G2; B) Suite Divino; C) Suite G1; D) Grupo Andrelândia; E) Complexo Mantiqueira; F) Complexo Juiz de Fora; G) Contato; H) Falha contracional; I) Cidade; J) Transcorrência destral. 

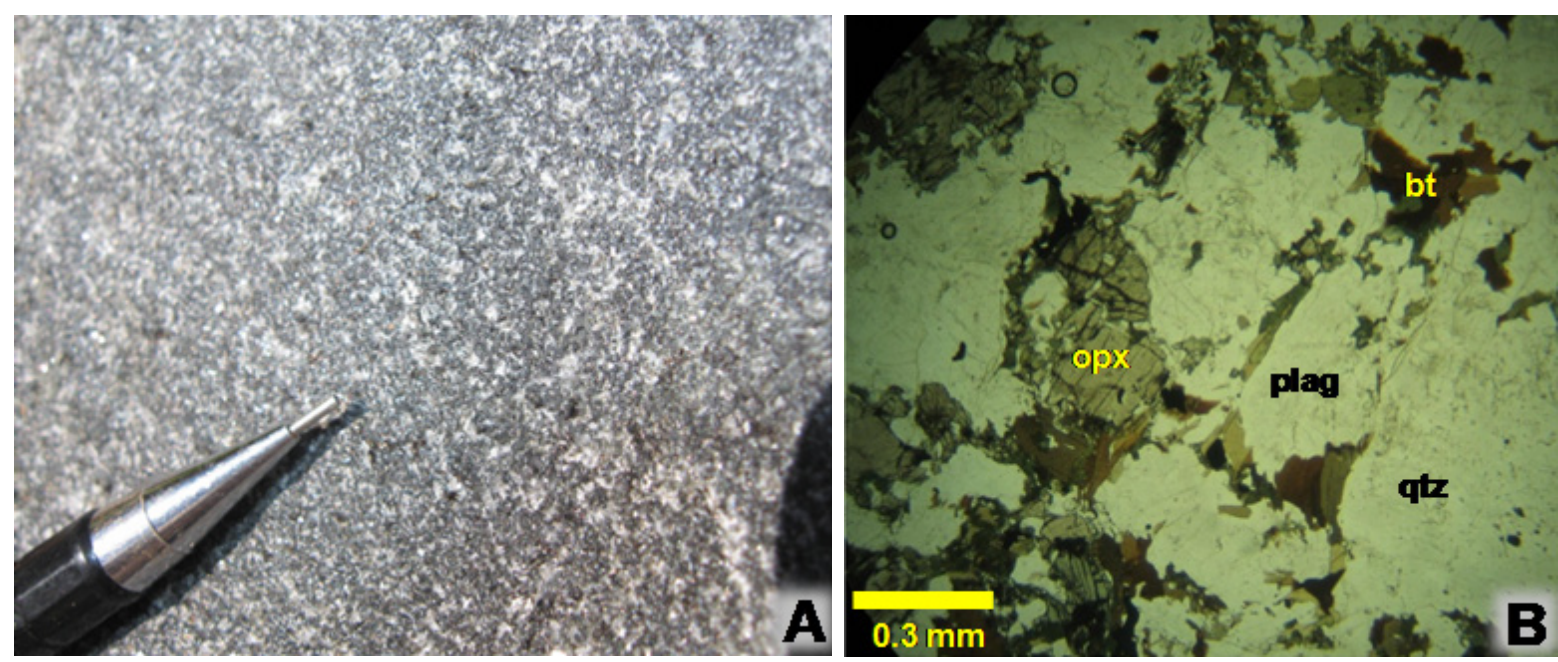

Figura 2 - Aspecto macroscópico e microscópico do charnockito da Suíte Divino. (A) Charnockito de granulação fina e aspecto maciço. (B) Fotomicrografia de charnockito tonalítico, nicóis paralelos.

ramentos intemperisados. A foliação é dada pelo alinhamento das palhetas de biotita, com cristais de piroxênio, anfibólio, quartzo e feldspato estirados na mesma direção. Localmente, cristais centimétricos de plagioclásio, feldspato potássico, ortopiroxênio e anfibólio conferem à rocha textura porfirítica (o último mineral é extremamente raro). Quando foliada, a fácies porfirítica apresenta-se protomilonítica, mostrando porfiroclastos de anfibólio, plagioclásio, feldspato potássico e ortopiroxênio rotacionados e com formação de sombra de pressão.

$\mathrm{O}$ fato da paragênese plagioclásio + quartzo + ortoclásio + hiperstênio + clinopiroxênio, apresentar-se orientada segundo a foliação regional indica que deformação e recristalização associada se deram em condições da fácies granulito. A mesma paragênese encontrase nas porções com textura ígnea preservada, porfiríticas, sugerindo que a cristalização magmática deu-se em condições PT igualmente elevadas. Processos incipientes de metamorfismo regressivo em condições da fácies anfibolito levaram à cristalização de hornblenda e biotita a partir da alteração de clinopiroxênio e hiperstênio.

As rochas da Suíte Divino, em termos petrográficos, podem ser divididas em três conjuntos (ácidas, intermediárias e básicas) conforme as proporções modais de quartzo, feldspato potássico, plagioclásio e minerais máficos. Esta divisão é confirmada pelos dados químicos, com base nos diferentes conteúdos de $\mathrm{SiO}_{2}$ (vide Tab. 1). Em média, o conjunto ácido é constituído de quartzo (38\%), feldspato potássico (26\%), minerais máficos (piroxênios + hornblenda + biotita + opacos $=$ $21 \%$ ) e plagioclásio (16\%). O conjunto intermediário é constituído, em média, por $33 \%$ de minerais máficos (piroxênios + hornblenda + biotita + opacos), $27 \%$ de plagioclásio, $26 \%$ de quartzo e $12 \%$ de feldspato potássico. A proporção modal para o conjunto básico é dada por $40 \%$ de minerais máficos (piroxênios + hornblenda + biotita + opacos), $29 \%$ de plagioclásio, $18 \%$ de quartzo e $13 \%$ de feldspato potássico. Os afloramentos individuais tendem a ser bastante homogêneos; rochas de composição ácida com encraves básicos foram descritas em um único local.

Os charnockitos podem exibir encraves decimétricos a métricos de granada-biotita gnaisse bandado, orientados segundo a foliação regional, que são interpretados como xenólitos da unidade metassedimentar. Em zonas de contato com esta unidade parece ocorrer a contaminação do charnockito, que enriquece-se em granada.

Litoquímica As análises geoquímicas foram realizadas em dois lotes. No primeiro, 11 amostras foram analisadas para elementos maiores, sendo nove pertencentes à Suíte Divino e duas representantes do embasamento (gnaisses ortoderivados do Complexo Juiz de Fora). As análises foram realizadas por Fluorescência de Raios X, no CPMTC (Centro de Pesquisa Prof. Manoel Teixeira da Costa, IGC-UFMG). As amostras passaram pelos processos convencionais de britagem, moagem e secagem, e foram fundidas e diluídas com tetraborato de lítio em recipientes de platina.

No segundo lote, 29 amostras foram analisadas para elementos maiores e traços (22 amostras da Suíte Divino e sete amostras do ortognaisse do Complexo Juiz de Fora). As 11 amostras do primeiro lote foram analisadas para elementos traços juntamente com o segundo lote. Estas 40 amostras passaram pelos processos de preparação convencionais, e em seguida enviadas para o laboratório $\mathrm{ACME}$, onde foram realizadas análises para elementos maiores e traços. Análises de rocha total deram-se por meio de fusão com metaborato de lítio, digestão com $\mathrm{HNO}_{3}$ e análise por ICP-ES para óxidos maiores e elementos menores. Elementos traços foram analisados por ICPMS (determinação de 45 elementos incluindo refratários e terras raras) por fusão com metaborato e tetraborato de litio. Metais-base foram digeridos com água régia e analisados por ICPMS.

INTERPRETAÇÃO DOS DADOS Os dados geoquímicos são apresentados na tabela 1 . No diagrama TAS, 
Tabela 1 - Composição química das rochas da Suite Divino e do Complexo Juiz de Fora, discriminadas quanto ao teor em sílica (ácidas com teor de SiO2 > 65\%; intermediárias 52\% < SiO2 < 65\% e básicas 45\% < SiO2 < 52\%).

\begin{tabular}{|c|c|c|c|c|c|c|c|c|c|c|c|c|c|c|c|c|}
\hline \multirow{2}{*}{$\frac{\text { Litotipo }}{\text { Amostra }}$} & \multicolumn{9}{|c|}{ SUÍTE DIVINO (MÁFICO) } & \multicolumn{7}{|c|}{ SUÍTE DIVINO (INTERMEDIÁRIO) } \\
\hline & R-5 & $\mathrm{T}-7$ & AM-30 & EC-60 A & $\mathrm{T}-1$ & EC-32C & $\mathrm{T}-10$ & R-3 & TJ-33 & AM-148 & TJ-38 B & GV-35 & T-8 & TJ-46 & T-4 & GV-6 \\
\hline $\mathrm{SiO} 2$ & 49,26 & 49,33 & 49,6 & 50 & 50,08 & 50,44 & 50,9 & 51,69 & 51,7 & 52,44 & 53 & 54 & 54,09 & 54,4 & 56,11 & 56,2 \\
\hline $\mathrm{TiO} 2$ & 2,58 & 2,08 & 2,28 & 1,21 & 1,9 & 0,73 & 1,5 & 1,83 & 0,79 & 1,35 & 1,03 & 0,54 & 1,45 & 1,52 & 1,74 & 0,71 \\
\hline $\mathrm{Al} 2 \mathrm{O} 3$ & 16,95 & 17,11 & 21 & 17 & 17,17 & 9,62 & 17,45 & 17,53 & 17,68 & 16,78 & 17,6 & 19,6 & 16,76 & 17,08 & 16,74 & 19 \\
\hline $\mathrm{Fe} 2 \mathrm{O} 3$ & 11,97 & 11,82 & 9,12 & 10 & 11,04 & 10,04 & 10,14 & 9,36 & 8,61 & 9,11 & 10 & 7,15 & 9,25 & 10,29 & 8,61 & 6,18 \\
\hline $\mathrm{MnO}$ & 0,16 & 0,17 & 0,15 & 0,32 & 0,18 & 0,18 & 0,16 & 0,15 & 0,12 & 0,13 & 0,17 & 0,12 & 0,14 & 0,18 & 0,16 & 0,1 \\
\hline $\mathrm{MgO}$ & 3,58 & 3,53 & 3,03 & 6,68 & 5,64 & 15,08 & 4,76 & 4,24 & 6,47 & 4,98 & 3,14 & 5,41 & 3,89 & 3,07 & 2,62 & 4,31 \\
\hline $\mathrm{CaO}$ & 6,92 & 6,21 & 6,86 & 8,63 & 7,8 & 9,45 & 8,08 & 7,6 & 7,89 & 7,73 & 6,48 & 5,89 & 7,34 & 6,35 & 5,37 & 5,32 \\
\hline $\mathrm{Na} 2 \mathrm{O}$ & 3,54 & 3,56 & 3,08 & 2,99 & 3,11 & 1,69 & 3,6 & 3,61 & 3,03 & 3,08 & 3,59 & 2,83 & 3,57 & 3,93 & 3,61 & 3,49 \\
\hline $\mathrm{K} 2 \mathrm{O}$ & 3,11 & 3,61 & 2,69 & 2,25 & 1,69 & 1,12 & 1,61 & 2,48 & 1,86 & 2,61 & 2,86 & 2,82 & 2,24 & 1,81 & 3,11 & 2,41 \\
\hline $\mathrm{P} 2 \mathrm{O} 5$ & 1,196 & 1,071 & 0,21 & 0,08 & 0,586 & 0,109 & 0,529 & 0,592 & 0,2 & 0,342 & 0,67 & 0,04 & 0,376 & 0,44 & 0,652 & 0,11 \\
\hline LOI & 0,3 & 0,8 & 1,2 & 1,7 & 0,4 & 1 & 0,8 & 0,5 & 1,2 & 1 & 0,83 & 1,2 & 0,5 & 0,5 & 0,8 & 1,3 \\
\hline TOTAL & 99,57 & 99,32 & \begin{tabular}{|c|}
99,22 \\
\end{tabular} & \begin{tabular}{|l|}
100,86 \\
\end{tabular} & 99,63 & 99,61 & 99,58 & \begin{tabular}{|l|}
99,62 \\
\end{tabular} & 99,55 & 99,62 & 99,37 & 99,6 & 99,6 & 99,57 & 99,5 & 99,13 \\
\hline $\mathrm{Cr}$ & $<0,002$ & 0,006 & & & 0,007 & 0,164 & 0,006 & \begin{tabular}{|l|}
0,005 \\
\end{tabular} & & 0,022 & & & $<0,002$ & 0,011 & 0,006 & \\
\hline $\mathrm{Ni}$ & $<20$ & 53 & & & 73 & 171 & 38 & 40 & & 50 & & & $<20$ & 70 & 53 & \\
\hline Co & 62,1 & 71,6 & 67,4 & 91,3 & 78 & 90,8 & 172,4 & 59,9 & 83,3 & 89,8 & 78,8 & 145,1 & 63 & 76,3 & 92,8 & 91,3 \\
\hline Sc & 22 & 27 & & & 30 & 47 & 31 & 23 & & 30 & & & 26 & 22 & 19 & \\
\hline $\mathrm{V}$ & 207 & 158 & 93 & 246 & 191 & 211 & 226 & 172 & 110 & 169 & 186 & 90 & 186 & 172 & 159 & 103 \\
\hline $\mathrm{Cu}$ & 23 & 22,4 & 13,9 & 16,2 & 28,9 & 89,3 & 24,8 & 29,8 & 25,6 & 17,5 & 25,7 & 75,5 & 18,5 & 25,6 & 15,3 & 14,1 \\
\hline $\mathrm{Pb}$ & 0,8 & 2,2 & 2 & 2,1 & 2,5 & 1,2 & 1,8 & 1,1 & 2,5 & 1,7 & 1,5 & 1,8 & 1,1 & 0,9 & 1,6 & 1,4 \\
\hline $\mathrm{Zn}$ & 48 & 112 & 50 & 111 & 42 & 17 & 49 & 40 & 31 & 65 & 59 & 20 & 59 & 31 & 64 & 19 \\
\hline $\mathrm{Rb}$ & 71,1 & 138,8 & 108,3 & 134,1 & 68,7 & 42,8 & 54,7 & 58,9 & 81,1 & 95 & 50,5 & 59,4 & 71,5 & 30,8 & 85,9 & 48,2 \\
\hline Cs & 0,3 & 1,3 & 0,8 & 0,8 & 0,9 & 0,4 & 0,4 & 0,3 & 2 & 1,3 & 0,3 & 0,3 & 0,4 & 0,1 & 0,5 & 0,1 \\
\hline $\mathrm{Ba}$ & 1906 & 2086 & 2609 & 358 & 562 & 360 & 745 & 1376 & 591 & 1447 & 1542 & 814 & 1078 & 1278 & 1613 & 1629 \\
\hline $\mathrm{Be}$ & 2 & 3 & $<1$ & 2 & 2 & $<1$ & 2 & 2 & 2 & 1 & 2 & 1 & $<1$ & $<1$ & 1 & 1 \\
\hline $\mathrm{Sr}$ & 633,2 & 509,3 & 582,9 & 243,4 & 547 & 247,8 & 691 & 629,9 & 594 & 594,6 & 666,8 & 321,6 & 472,3 & 449,1 & 496,3 & 808,3 \\
\hline $\mathrm{Ga}$ & 20 & 26,2 & 19,5 & 19,2 & 20,8 & 11,7 & 20,3 & 20 & 15,9 & 19,9 & 21,7 & 16,5 & 21,2 & 21,7 & 21,1 & 16,9 \\
\hline $\mathrm{Ta}$ & 1,2 & 1,9 & 1,1 & 0,4 & 1,1 & 0,3 & 1 & 1,1 & 0,5 & 0,5 & 1,2 & 0,5 & 1,1 & 1,1 & 1,6 & 0,4 \\
\hline $\mathrm{Nb}$ & 25,4 & 47,9 & 29,5 & 10,9 & 19,7 & 6,8 & 20,4 & 25,2 & 14,1 & 13,6 & 31,6 & 6,2 & 27,1 & 21,2 & 29,6 & 5,5 \\
\hline $\mathrm{Hf}$ & 8,9 & 18 & 16,1 & 2,2 & 5 & 2,7 & 4,6 & 7,1 & 5,1 & 6,7 & 9,7 & 3,7 & 8,1 & 9,8 & 8 & 7,2 \\
\hline $\mathrm{Zr}$ & 355 & 773,9 & 646,8 & 70 & 244,8 & 97,8 & 168,8 & \begin{tabular}{|l|}
275,7 \\
\end{tabular} & 201,5 & 255,9 & 378,5 & 135,3 & 334,6 & 458,9 & 344,8 & 254,7 \\
\hline $\mathrm{Ti}$ & 0,2 & 0,4 & 0,2 & 0,7 & 0,2 & 0,2 & 0,2 & 0,2 & 0,4 & 0,4 & 0,1 & $<0,1$ & 0,3 & $<0,1$ & 0,3 & $<0,1$ \\
\hline Y & 44,3 & 113,7 & 31,9 & 77,8 & 34,9 & 27,6 & 50 & 37,8 & 25,1 & 27,8 & 45,5 & 11 & 36 & 31,9 & 56,3 & 9,2 \\
\hline $\mathrm{Th}$ & 1,2 & 8 & 5,6 & 0,9 & 1,3 & 2,6 & 3,3 & 1,1 & 3,5 & 2,4 & 2,1 & 0,4 & 3,7 & 0,9 & 1,7 & $<0,2$ \\
\hline $\mathrm{U}$ & 0,4 & 0,8 & 1,1 & 0,3 & 0,4 & 0,4 & 0,4 & 0,3 & 1,3 & 0,5 & 0,5 & 0,2 & 0,5 & 0,4 & 0,5 & 0,5 \\
\hline $\mathrm{La}$ & 67 & 149,5 & 66,5 & 33,7 & 37,9 & 15,4 & 53 & 51,5 & 39 & 45,1 & 77,8 & 15 & 44,8 & 31,2 & 47 & 17 \\
\hline $\mathrm{Ce}$ & 143,4 & 340,2 & 128,4 & 86,1 & 86,7 & 37,6 & 118,6 & \begin{tabular}{|l|}
111,8 \\
\end{tabular} & 72,4 & 92,5 & 162,3 & 25,8 & 93,2 & 68,7 & 116,1 & 32,1 \\
\hline $\operatorname{Pr}$ & 18,16 & 43,18 & 16,22 & 12,49 & 11,44 & 5,57 & 15,48 & 14,6 & 8,72 & 11,52 & 22,44 & 3,15 & 11,67 & 8,72 & 16,07 & 3,85 \\
\hline $\mathrm{Nd}$ & 73,4 & 179,8 & 63,5 & 52,4 & 54,1 & 24,9 & 67,9 & 64,2 & 33 & 46,8 & 94,6 & 13 & 51,6 & 41,1 & 69,9 & 14,3 \\
\hline $\mathrm{Sm}$ & 12,22 & 32,88 & 10,75 & 13,15 & 9,84 & 5,45 & 13,05 & 10,89 & 5,86 & 9,08 & 16,57 & 2,65 & 9,08 & 7,8 & 14,1 & 2,64 \\
\hline $\mathrm{Eu}$ & 3,41 & 4,36 & 3,35 & 1,8 & 2,22 & 1,13 & 2,58 & 1,52 & 1,47 & 1,86 & 3,19 & 1,58 & 2,12 & 3,19 & 2,92 & 1,27 \\
\hline $\mathrm{Gd}$ & 10,4 & 26,53 & 8,1 & 12,94 & 8,05 & 5,28 & 10,61 & 8,91 & 5,09 & 6,85 & 13,06 & 2,33 & 7,65 & 7,1 & 11,66 & 2,16 \\
\hline $\mathrm{Tb}$ & 1,64 & 4,19 & 1,21 & 2,37 & 1,3 & 0,89 & 1,76 & 0,41 & 0,81 & 1,05 & 1,86 & 0,37 & 1,24 & 1,13 & 2 & 0,35 \\
\hline Dy & 8,11 & 23,16 & 6,13 & 13,93 & 6,67 & 4,88 & 9,24 & 7,07 & 4,47 & 5,61 & 10,03 & 2,17 & 6,44 & 5,9 & 10,75 & 1,76 \\
\hline Ho & 1,57 & 4,21 & 1,08 & 2,89 & 1,25 & 0,98 & 1,8 & 1,39 & 0,89 & 1,07 & 1,9 & 0,43 & 1,28 & 1,2 & 1,99 & 0,33 \\
\hline Er & 4,07 & 11,68 & 2,94 & 8,53 & 3,37 & 2,79 & 5,08 & 3,69 & 2,62 & 2,9 & 4,87 & 1,22 & 3,62 & 3,4 & 5,9 & 0,92 \\
\hline $\mathrm{Tm}$ & 0,56 & 1,71 & 0,45 & 1,29 & 0,5 & 0,43 & 0,69 & 0,51 & 0,4 & 0,39 & 0,71 & 0,19 & 0,52 & 0,48 & 0,8 & 0,14 \\
\hline $\mathrm{Yb}$ & 3,54 & 9,91 & 2,76 & 7,94 & 3,01 & 2,49 & 4,49 & 3,22 & 2,6 & 2,28 & 3,97 & 1,18 & 3,37 & 3,32 & 4,86 & 0,93 \\
\hline $\mathrm{Lu}$ & 0,52 & 1,38 & 0,4 & 1,11 & 0,47 & 0,37 & 0,65 & 0,46 & 0,38 & 0,33 & 0,59 & 0,18 & 0,52 & 0,5 & 0,69 & 0,15 \\
\hline Mo & 1,3 & 1,5 & 1,2 & 0,7 & 1,1 & 0,7 & 1,3 & 0,7 & 1 & 0,8 & 1,3 & 1,4 & 1,4 & 1,2 & 1,5 & 0,7 \\
\hline $\mathrm{Ni}$ & 3,5 & 13,2 & 7,7 & 49,5 & 27,2 & 116,5 & 19,8 & 33,8 & 59,4 & 33,7 & 17,1 & 73,9 & 7 & 10,1 & 5,2 & 17,9 \\
\hline As & $<0,5$ & $<0,5$ & $<0,5$ & 0,6 & $<0,5$ & $<0,5$ & $<0,5$ & $<0,5$ & $<0,5$ & $<0,5$ & $<0,5$ & $<0,5$ & $<0,5$ & $<0,5$ & $<0,5$ & 0,5 \\
\hline $\mathrm{Cd}$ & $<0,1$ & $<0,1$ & $<0,1$ & $<0,1$ & $<0,1$ & $<0,1$ & $<0,1$ & $<0,1$ & $<0,1$ & $<0,1$ & $<0,1$ & $<0,1$ & $<0,1$ & $<0,1$ & $<0,1$ & $<0,1$ \\
\hline $\mathrm{Sb}$ & $<0,1$ & $<0,1$ & $<0,1$ & $<0,1$ & $<0,1$ & $<0,1$ & $<0,1$ & $<0,1$ & $<0,1$ & $<0,1$ & $<0,1$ & $<0,1$ & $<0,1$ & $<0,1$ & $<0,1$ & $<0,1$ \\
\hline $\mathrm{Bi}$ & $<0,1$ & $<0,1$ & $<0,1$ & $<0,1$ & $<0,1$ & $<0,1$ & $<0,1$ & $<0,1$ & $<0,1$ & $<0,1$ & $<0,1$ & $<0,1$ & $<0,1$ & $<0,1$ & $<0,1$ & $<0,1$ \\
\hline $\mathrm{Ag}$ & $<0,1$ & $<0,1$ & $<0,1$ & $<0,1$ & $<0,1$ & $<0,1$ & $<0,1$ & $<0,1$ & $<0,1$ & $<0,1$ & $<0,1$ & $<0,1$ & $<0,1$ & $<0,1$ & $<0,1$ & $<0,1$ \\
\hline $\mathrm{Au}$ & $<0,5$ & $<0,5$ & 0,8 & $<0,5$ & $<0,5$ & 1,3 & 0,6 & $<0,5$ & 1,8 & 1 & 1,7 & 1,4 & $<0,5$ & 1 & $<0,5$ & $<0,5$ \\
\hline $\mathrm{Hg}$ & $<0,01$ & $<0,01$ & $<0,01$ & $<0,01$ & $<0,01$ & $<0,01$ & $<0,01$ & $<0,01$ & $<0,01$ & $<0,01$ & $<0,01$ & $<0,01$ & $<0,01$ & $<0,01$ & $<0,01$ & $<0,01$ \\
\hline $\mathrm{Se}$ & $<0,5$ & 1,2 & 0,6 & 0,8 & $<0,5$ & 0,5 & 0,6 & $<0,5$ & $<0,5$ & 0,5 & 1,1 & 0,7 & $<0,5$ & $<0,5$ & $<0,5$ & $<0,5$ \\
\hline Sn & 1 & 5 & 2 & 6 & 1 & 1 & 3 & 1 & 2 & 1 & 3 & $<1$ & $<1$ & $<1$ & 3 & 1 \\
\hline W & 189,4 & 324,2 & 274,6 & 304,9 & 327,9 & 201,2 & 562 & 183 & 252,5 & 357,2 & 253,8 & 576,2 & 276 & 392,7 & 550 & 406,5 \\
\hline
\end{tabular}


Tabela 1 - Continuação.

\begin{tabular}{|c|c|c|c|c|c|c|c|c|c|c|c|c|c|c|c|}
\hline \multirow{2}{*}{$\frac{\text { Litotipo }}{\text { Amostra }}$} & \multicolumn{9}{|c|}{ SUÍTE DIVINO (INTERMEDIÁRIO) } & \multicolumn{6}{|c|}{ SUÍTE DIVINO (ÁCIDO) } \\
\hline & $\mathrm{T}-16$ & $\mathrm{~T}-15$ & TJ-38 A & $\mathrm{T}-11$ & AM-161 & TJ-56 & $\mathrm{T}-9$ & $\mathrm{~T}-5$ & EC-89 & GV-37 & $\mathrm{T}-2$ & GV-152A & EC-63 & EC-60 B & EC-164A \\
\hline $\mathrm{SiO} 2$ & 56,73 & 57,1 & 57,3 & 57,64 & 60,08 & 60,17 & 60,25 & 62,45 & 64,9 & 65,22 & 66,07 & 66,83 & 66,87 & 68,6 & 71,57 \\
\hline $\mathrm{TiO} 2$ & 1,22 & 1,22 & 1,28 & 1,3 & 0,66 & 0,65 & 1,42 & 0,99 & 0,57 & 0,87 & 0,19 & 0,72 & 0,68 & 0,08 & 0,36 \\
\hline $\mathrm{A} 12 \mathrm{O} 3$ & 5,21 & 16,31 & 17,7 & 16,99 & 16,1 & 15,5 & 15,18 & 16,38 & 17,3 & 15 & 14,68 & 14,29 & 15,08 & 19,3 & 13,46 \\
\hline $\mathrm{Fe} 2 \mathrm{O} 3$ & 7,69 & 7,59 & 5,86 & 7,33 & 7,48 & 7,31 & 7,78 & 5,75 & 4,31 & 7,08 & 2,56 & 5,27 & 3,74 & 0,7 & 4,1 \\
\hline $\mathrm{MnO}$ & 0,12 & 0,11 & 0,1 & 0,11 & 0,12 & 0,11 & 0,14 & 0,08 & 0,08 & 0,28 & 0,07 & 0,07 & 0,11 & 0,01 & 0,06 \\
\hline $\mathrm{MgO}$ & 3,77 & 3,55 & 2 & 2,07 & 3,24 & 3,2 & 1,84 & 1,84 & 0,65 & 1,97 & 1,6 & 1,67 & 0,62 & 0,26 & 0,94 \\
\hline $\mathrm{CaO}$ & 6,24 & 6,23 & 3,98 & 4,61 & 4,93 & 5,38 & 3,75 & 3,51 & 2,12 & 3,52 & 3,33 & 3,65 & 2,53 & 1,42 & 2,55 \\
\hline $\mathrm{Na} 2 \mathrm{O}$ & 3,35 & 3,57 & 3,85 & 3,69 & 3,8 & 3,51 & 3,7 & 3,56 & 3,24 & 2,86 & 2,53 & 2,69 & 3,22 & 2,41 & 3,32 \\
\hline $\mathrm{K} 2 \mathrm{O}$ & 3,15 & 2,62 & 5,89 & 4,15 & 2,49 & 2,48 & 4,01 & 3,81 & 5,62 & 1,8 & 7,19 & 3,23 & 5,76 & 5,73 & 2,63 \\
\hline $\mathrm{P} 2 \mathrm{O} 5$ & 0,397 & 0,386 & 0,37 & 0,458 & 0,327 & 0,294 & 0,583 & 0,326 & 0,16 & 0,003 & 0,276 & 0,249 & 0,14 & 0,03 & 0,056 \\
\hline LOI & 0,7 & 0,9 & 0,81 & 1,2 & 0,5 & 1 & 0,8 & 0,9 & 0,8 & 1 & 0,8 & 1 & 0,8 & 0,6 & 0,7 \\
\hline TOTAL & 99,59 & 99,57 & 99,14 & 99,55 & 99,73 & 99,63 & 99,47 & 99,58 & 99,75 & 99,66 & 99,32 & 99,71 & 99,6 & 99,14 & 99,78 \\
\hline $\mathrm{Cr}$ & 0,015 & 0,009 & & 0,003 & 0,008 & 0,012 & $<0,002$ & 0,012 & & 0,015 & 0,005 & 0,004 & $<0,002$ & & $<0,002$ \\
\hline $\mathrm{Ni}$ & 79 & 66 & & 43 & 40 & 58 & 28 & 72 & & 39 & 72 & $<20$ & $<20$ & & $<20$ \\
\hline Co & 75,7 & 96,2 & 103,9 & 78,2 & 114,5 & 101,2 & 224,1 & 106,5 & 140,5 & 201,8 & 117,6 & 139,7 & 127,2 & 234,1 & 177,4 \\
\hline $\mathrm{Sc}$ & 18 & 18 & & 15 & 23 & 16 & 15 & 10 & & 32 & 20 & 12 & 12 & & 15 \\
\hline $\mathrm{V}$ & 129 & 121 & 218 & 110 & 105 & 108 & 81 & 36 & 23 & 123 & 29 & 85 & 10 & $<8$ & 25 \\
\hline $\mathrm{Cu}$ & 23,9 & 23,1 & 27,4 & 12,8 & 24,9 & 14,7 & 16,9 & 11,7 & 6,6 & 17,8 & 40,9 & 35,1 & 6,3 & 3,7 & 30,2 \\
\hline $\mathrm{Pb}$ & 1,1 & 1,1 & 1,7 & 1,3 & 2,9 & 0,9 & 4,1 & 2,4 & 2,1 & 3,3 & 2,8 & 1,7 & 2,1 & 4 & 2,3 \\
\hline $\mathrm{Zn}$ & 52 & 49 & 61 & 48 & 57 & 27 & 82 & 64 & 31 & 40 & 21 & 27 & 54 & 11 & 61 \\
\hline $\mathrm{Rb}$ & 83,1 & 76,1 & 53,8 & 95,7 & 75,7 & 69,2 & 114,8 & 128,7 & 87,5 & 88,6 & 134,9 & 60,9 & 129,6 & 148,4 & 62,1 \\
\hline $\mathrm{Cs}$ & 0,4 & 0,3 & 0,3 & 0,4 & 0,3 & 0,2 & 1,2 & 1,8 & 0,1 & 0,8 & 1,6 & $<0,1$ & 0,2 & 0,8 & 0,6 \\
\hline $\mathrm{Ba}$ & 1160 & 1221 & 1525 & 1626 & 826 & 729 & 1011 & 1087 & 1308 & 461 & 3364 & 1088 & 2411 & 1607 & 706 \\
\hline $\mathrm{Be}$ & 2 & 2 & 2 & 3 & 1 & 2 & 2 & 2 & 1 & 1 & $<1$ & 2 & 1 & $<1$ & $<1$ \\
\hline $\mathrm{Sr}$ & 500,5 & 551,4 & 630,1 & 478,9 & 516,8 & 512,4 & 320,4 & \begin{tabular}{|l|}
416,7 \\
\end{tabular} & \begin{tabular}{|l|}
187,9 \\
\end{tabular} & 349 & 775,3 & 339 & 261,4 & 299,6 & 209,1 \\
\hline $\mathrm{Ga}$ & 18,9 & 20 & 22,8 & 20,7 & 21,3 & 18,6 & 19,7 & 20,1 & 17,8 & 18,9 & 13,1 & 15,7 & 20,3 & 11,1 & 17,9 \\
\hline $\mathrm{Ta}$ & 0,8 & 0,8 & 1,5 & 1,1 & 0,3 & 0,6 & 2 & 1,1 & 1 & 1 & 0,4 & 1,6 & 1,2 & 0,4 & 0,7 \\
\hline $\mathrm{Nb}$ & 18,1 & 18,6 & 37,4 & 23,4 & 8,3 & 12,2 & 32,7 & 19,1 & 15 & 19,4 & 3,2 & 13,7 & 31,1 & 2 & 9,4 \\
\hline $\mathrm{Hf}$ & 10,2 & 4,5 & 10,6 & 11,6 & 5,1 & 5,1 & 12,5 & 6,2 & 10 & 25,9 & 2,8 & 5,3 & 18,7 & 2,1 & 9,1 \\
\hline $\mathrm{Zr}$ & 420,3 & 170,6 & 394,7 & 462,3 & 177,9 & 189,6 & 507,6 & 227,9 & 363,4 & 861,2 & 94,2 & 179,8 & 698 & 53 & 293,5 \\
\hline $\mathrm{Ti}$ & 0,3 & 0,2 & 0,2 & 0,2 & 0,3 & 0,2 & 0,3 & 0,4 & $<0,1$ & 0,4 & 0,1 & $<0,1$ & 0,1 & 0,2 & 0,2 \\
\hline $\mathrm{Y}$ & 31 & 29,7 & 65,2 & 35,1 & 40,2 & 21,8 & 49,8 & 26,3 & 16,5 & 114,3 & 30,8 & 12,5 & 36,5 & 4,9 & 12,4 \\
\hline Th & 1.2 & 1 & 1,5 & 4,2 & 33,6 & 1 & 7,2 & 22,8 & 0,5 & 6,3 & 8,1 & 0,4 & 1,7 & 4,9 & 21,4 \\
\hline $\mathrm{U}$ & 0,2 & $<0,1$ & 0,3 & 0,7 & 0,5 & 0,3 & 1,5 & 1,3 & 0,4 & 0,8 & 3,2 & 0,2 & 0,3 & 0,4 & 1,2 \\
\hline $\mathrm{La}$ & 52,2 & 46,8 & 86,7 & 63,5 & 179,9 & 38,5 & 72,4 & 114,5 & 28,3 & 58 & 53,1 & 44 & 37 & 15,7 & 67 \\
\hline $\mathrm{Ce}$ & 111,6 & 102,4 & 190,1 & 132,9 & 354,3 & 77,7 & 161,8 & 246,8 & 52 & 73,7 & 113,7 & 80,4 & 75,8 & 20,9 & 129,7 \\
\hline $\operatorname{Pr}$ & 13,58 & 12,46 & 25,93 & 15,97 & 41,16 & 9,17 & 20,11 & 24,56 & 6,44 & 7,9 & 13,64 & 9,23 & 9,81 & 2,68 & 15,18 \\
\hline $\mathrm{Nd}$ & 57 & 53,1 & 108,1 & 65,7 & 147,9 & 36,5 & 83,6 & 87,1 & 25,8 & 24,2 & 54,6 & 34 & 42,6 & 8,3 & 57,8 \\
\hline $\mathrm{Sm}$ & 9,53 & 8,75 & 20,89 & 10,35 & 20,12 & 6,25 & 14,6 & 11,93 & 5,1 & 3,08 & 9,18 & 4,91 & 8,79 & 1,6 & 8,25 \\
\hline $\mathrm{Eu}$ & 2,08 & 2,15 & 3,5 & 2,37 & 1,95 & 1,44 & 1,96 & 1,88 & 2,34 & 2,41 & 2,34 & 1,88 & 4,79 & 0,95 & 1,29 \\
\hline $\mathrm{Gd}$ & 7,23 & 7,01 & 17,07 & 8,11 & 11,74 & 4,86 & 11,7 & 6,76 & 4,38 & 3,5 & 6,87 & 3,47 & 7,76 & 1,01 & 4,78 \\
\hline $\mathrm{Tb}$ & 1,17 & 1,14 & 2,55 & 1,31 & 1,71 & 0,78 & 1,87 & 1,12 & 0,64 & 1,02 & 1,17 & 0,47 & 1,29 & 0,15 & 0,6 \\
\hline Dy & 6,01 & 5,84 & 13,34 & 6,53 & 8,21 & 3,82 & 9,52 & 5,16 & 3,41 & 11,45 & 6,11 & 2,41 & 7,18 & 0,92 & 2,67 \\
\hline Ho & 1,1 & 1,11 & 2,43 & 1,29 & 1,39 & 0,75 & 1,82 & 0,94 & 0,65 & 4,2 & 1,09 & 0,45 & 1,36 & 0,19 & 0,43 \\
\hline Er & 3,08 & 2,89 & 6,46 & 3,52 & 3,79 & 2,2 & 5,04 & 2,53 & 1,74 & 18,91 & 3,09 & 1,17 & 3,7 & 0,48 & 1,11 \\
\hline $\mathrm{Tm}$ & 0,47 & 0,44 & 0,86 & 0,52 & 0,55 & 0,31 & 0,69 & 0,35 & 0,23 & 3,93 & 0,43 & 0,18 & 0,57 & 0,07 & 0,18 \\
\hline $\mathrm{Yb}$ & 2,84 & 2,56 & 5,02 & 3,17 & 3,13 & 2,04 & 4,29 & 2,32 & 1,52 & 30,91 & 2,63 & 1,17 & 3,42 & 0,42 & 1,18 \\
\hline $\mathrm{Lu}$ & 0,44 & 0, & 0,68 & 0,45 & 0,48 & 0,28 & 0,61 & 0,31 & 0,24 & 5,31 & 0,38 & 0,19 & 0,54 & 0,08 & 0,2 \\
\hline Mo & 0,9 & 0,9 & 1,2 & 1,6 & 1,4 & 1,1 & 3,7 & 1,9 & 2,1 & 2,7 & 1,8 & 1,9 & 2,7 & 2,6 & 2,5 \\
\hline $\mathrm{Ni}$ & 34,6 & 24,2 & 17,6 & 6,4 & 29,1 & 15,4 & 8,7 & 13,2 & 7,4 & 33,5 & 30,2 & 12,1 & 4 & 6,9 & 7,3 \\
\hline As & $<0,5$ & $<0,5$ & $<0,5$ & $<0,5$ & $<0,5$ & $<0,5$ & $<0,5$ & $<0,5$ & 0,7 & $<0,5$ & 0,5 & $<0,5$ & $<0,5$ & $<0,5$ & $<0,5$ \\
\hline $\mathrm{Cd}$ & $<0,1$ & $<0,1$ & $<0,1$ & $<0,1$ & $<0,1$ & $<0,1$ & $<0,1$ & $<0,1$ & $<0,1$ & $<0,1$ & $<0,1$ & $<0,1$ & $<0,1$ & $<0,1$ & $<0,1$ \\
\hline $\mathrm{Sb}$ & $<0,1$ & $<0,1$ & $<0,1$ & $<0,1$ & $<0,1$ & $<0,1$ & $<0,1$ & $<0,1$ & $<0,1$ & $<0,1$ & $<0,1$ & $<0,1$ & $<0,1$ & $<0,1$ & $<0,1$ \\
\hline $\mathrm{Bi}$ & $<0,1$ & $<0,1$ & $<0,1$ & $<0,1$ & $<0,1$ & $<0,1$ & $<0,1$ & $<0,1$ & $<0,1$ & $<0,1$ & $<0,1$ & $<0,1$ & $<0,1$ & $<0,1$ & $<0,1$ \\
\hline $\mathrm{Ag}$ & $<0,1$ & $<0,1$ & $<0,1$ & $<0,1$ & $<0,1$ & $<0,1$ & $<0,1$ & $<0,1$ & $<0,1$ & $<0,1$ & $<0,1$ & $<0,1$ & $<0,1$ & $<0,1$ & $<0,1$ \\
\hline $\mathrm{Au}$ & 1,1 & $<0,5$ & 22,6 & 1,6 & 2,3 & $<0,5$ & 1 & $<0,5$ & 0,9 & 1,2 & 2,1 & 1,9 & 0,8 & $<0,5$ & 2,3 \\
\hline $\mathrm{Hg}$ & $<0,01$ & $<0,01$ & $<0,01$ & $<0,01$ & $<0,01$ & $<0,01$ & $<0,01$ & $<0,01$ & $<0,01$ & $<0,01$ & $<0,01$ & $<0,01$ & $<0,01$ & $<0,01$ & $<0,01$ \\
\hline $\mathrm{Se}$ & 0,6 & $<0,5$ & 0,9 & $<0,5$ & 0,9 & $<0,5$ & 0,6 & $<0,5$ & $<0,5$ & $<0,5$ & $<0,5$ & $<0,5$ & $<0,5$ & $<0,5$ & $<0,5$ \\
\hline $\mathrm{Sn}$ & 1 & $<1$ & 3 & 1 & 1 & 2 & 2 & 3 & $<1$ & $<1$ & 2 & $<1$ & $<1$ & 1 & $<1$ \\
\hline $\mathrm{W}$ & 394,5 & 532,6 & 369,1 & 487,5 & 511,2 & 552,2 & 1099 & 800,3 & \begin{tabular}{|l|}
710,4 \\
\end{tabular} & 1111 & 892,3 & 750,7 & 704,9 & 1111 & 1016 \\
\hline
\end{tabular}


Tabela 1 - Continuação.

\begin{tabular}{|c|c|c|c|c|c|c|c|c|c|}
\hline \multirow{2}{*}{$\begin{array}{l}\text { Litotipo } \\
\text { Amostra } \\
\end{array}$} & \multicolumn{3}{|c|}{ CJF (gnaisse máfico) } & \multicolumn{5}{|c|}{ CJF (gnaisse intermediário) } & \multirow{2}{*}{$\begin{array}{c}\text { CJF (gnaisse ácido) } \\
\text { R-6 }\end{array}$} \\
\hline & AM-181 & EC-46 & GV-25 & EC-8 & AM-22 & AM-27 & GV-197 & EC-74 & \\
\hline $\mathrm{SiO} 2$ & 46,22 & 48,36 & 50,49 & 56,7 & 57,2 & 58,31 & 62,73 & 64,29 & 65,31 \\
\hline $\mathrm{TiO} 2$ & 1,22 & 1,39 & 1,55 & 1,05 & 0,63 & 1,66 & 0,73 & 0,74 & 0,69 \\
\hline $\mathrm{A} 12 \mathrm{O} 3$ & 17,58 & 16,69 & 15,62 & 18,6 & 19,6 & 15,9 & 14,68 & 15,07 & 16,27 \\
\hline $\mathrm{Fe} 2 \mathrm{O} 3$ & 14,7 & 10,69 & 10,98 & 7,02 & 6,24 & 8,27 & 6,84 & 5,14 & 4,71 \\
\hline $\mathrm{MnO}$ & 0,21 & 0,19 & 0,18 & 0,17 & 0,09 & 0,13 & 0,09 & 0,07 & 0,06 \\
\hline $\mathrm{MgO}$ & 5,87 & 8,02 & 7,74 & 2,42 & 3,5 & 2,82 & 3,12 & 2,61 & 1,5 \\
\hline $\mathrm{CaO}$ & 10,66 & 9,56 & 9,65 & 4,44 & 5,7 & 4,95 & 4,24 & 1,63 & 4,42 \\
\hline $\mathrm{Na} 2 \mathrm{O}$ & 2,57 & 3,02 & 2,49 & 3,74 & 2,55 & 3,01 & 3,04 & 2,36 & 4,03 \\
\hline $\mathrm{K} 2 \mathrm{O}$ & 0,51 & 0,73 & 0,62 & 2,73 & 3,58 & 3,61 & 2,83 & 6,8 & 1,79 \\
\hline $\mathrm{P} 2 \mathrm{O} 5$ & 0,074 & 0,221 & 0,192 & 0,27 & 0,18 & 0,601 & 0,172 & 0,139 & 0,174 \\
\hline LOI & 0,2 & 0,8 & 0,2 & 2,11 & 0,5 & & 1,2 & 0,7 & 0,8 \\
\hline TOTAL & 99,81 & 99,67 & 99,79 & 99,25 & 99,77 & & 99,68 & 99,58 & 99,75 \\
\hline $\mathrm{Cr}$ & $<0,002$ & 0,032 & 0,058 & & & 0,006 & 0,011 & 0,004 & 0,006 \\
\hline $\mathrm{Ni}$ & 21 & 78 & 128 & & & 29 & 46 & $<20$ & 29 \\
\hline Co & 86,3 & 101,2 & 86,6 & 90,8 & 113,4 & 98,9 & 119,9 & 107,5 & 124 \\
\hline $\mathrm{Sc}$ & 38 & 33 & 39 & & & 17 & 13 & 9 & 8 \\
\hline $\mathrm{V}$ & 490 & 207 & 223 & 111 & 98 & 133 & 75 & 72 & 97 \\
\hline $\mathrm{Cu}$ & 53,6 & 42,1 & 1,5 & 18,5 & 10,2 & 28,6 & 32,4 & 35,3 & 6,8 \\
\hline $\mathrm{Pb}$ & 1,9 & 0,9 & 1,9 & 2,5 & 1,7 & 1,4 & 1 & 3,2 & 0,9 \\
\hline $\mathrm{Zn}$ & 25 & 26 & 15 & 76 & 36 & 37 & 28 & 40 & 24 \\
\hline $\mathrm{Rb}$ & 8,4 & 15,6 & 9,9 & 76,6 & 86,9 & 78,7 & 55,8 & 197,1 & 42,2 \\
\hline Cs & $<0,1$ & 0,1 & $<0,1$ & 0,1 & 0,2 & 0,2 & $<0,1$ & 0,9 & 0,3 \\
\hline $\mathrm{Ba}$ & 220 & 436 & 77 & 952 & 1171 & 1675 & 858 & 1908 & 788 \\
\hline $\mathrm{Be}$ & $<1$ & $<1$ & 2 & 3 & 2 & 2 & 2 & $<1$ & 2 \\
\hline $\mathrm{Sr}$ & 202,8 & 388,1 & 281,4 & 429,6 & 529,2 & 520,6 & 401,5 & 361,1 & 575,4 \\
\hline $\mathrm{Ga}$ & 17,6 & 17,5 & 17,1 & 20,6 & 19,1 & 18,7 & 17,5 & 17,3 & 19,9 \\
\hline $\mathrm{Ta}$ & 0,1 & 0,3 & 0,8 & 1,3 & 0,5 & 1,1 & 0,5 & 0,4 & 0,6 \\
\hline $\mathrm{Nb}$ & 2,4 & 5,1 & 12,1 & 26,9 & 8,5 & 26,4 & 10,4 & 9,4 & 11,3 \\
\hline $\mathrm{Hf}$ & 1,3 & 3,5 & 2 & 9 & 6,5 & 15,1 & 8 & 17,2 & 7,1 \\
\hline $\mathrm{Zr}$ & 45,4 & 128,4 & 60,4 & 304,5 & 215,5 & 601,1 & 254,6 & 655,8 & 272,9 \\
\hline $\mathrm{Ti}$ & $<0,1$ & $<0,1$ & $<0,1$ & 0,2 & 0,2 & 0,2 & 0,1 & 0,4 & 0,1 \\
\hline $\mathrm{Y}$ & 13 & 33,4 & 20,8 & 43,4 & 24,8 & 39,3 & 13,7 & 14,3 & 10,7 \\
\hline $\mathrm{Th}$ & 0,8 & 1 & 1,7 & 8,3 & 1 & 0,4 & 1,3 & 47,3 & 2,7 \\
\hline $\mathrm{U}$ & 0,2 & 0,2 & 0,4 & 0,5 & 0,4 & 0,3 & 0,4 & 2,9 & 0,5 \\
\hline $\mathrm{La}$ & 8,1 & 12,6 & 16,6 & 67 & 34,4 & 58,1 & 33,3 & 156,3 & 34,7 \\
\hline $\mathrm{Ce}$ & 17,1 & 29,3 & 40,6 & 132,7 & 70,4 & 129,7 & 65,5 & 288,8 & 60,3 \\
\hline $\operatorname{Pr}$ & 2,09 & 4,08 & 5,59 & 16,37 & 8,95 & 17,36 & 8,14 & 31,95 & 6,55 \\
\hline $\mathrm{Nd}$ & 9,1 & 20,6 & 23,9 & 63,7 & 33,9 & 73,6 & 32,6 & 112,3 & 23,9 \\
\hline $\mathrm{Sm}$ & 2,07 & 4,63 & 5,68 & 11,78 & 6,55 & 13,55 & 5,37 & 13,24 & 3,63 \\
\hline $\mathrm{Eu}$ & 0,88 & 1,66 & 1,36 & 2,73 & 1,44 & 2,66 & 1,28 & 1,95 & 1,54 \\
\hline $\mathrm{Gd}$ & 2,02 & 5,08 & 5,29 & 9,66 & 5,47 & 9,76 & 4 & 6,73 & 2,46 \\
\hline $\mathrm{Tb}$ & 0,36 & 0,96 & 0,89 & 1,49 & 0,85 & 1,43 & 0,6 & 0,85 & 0,37 \\
\hline Dy & 2,22 & 5,51 & 4,68 & 8,3 & 4,87 & 7,2 & 2,98 & 3,17 & 2 \\
\hline Ho & 0,49 & 1,18 & 0,83 & 1,6 & 0,91 & 1,36 & 0,51 & 0,48 & 0,37 \\
\hline $\mathrm{Er}$ & 1,45 & 3,54 & 2,01 & 4,56 & 2,51 & 3,68 & 1,37 & 1,05 & 0,96 \\
\hline $\mathrm{Tm}$ & 0,23 & 0,51 & 0,3 & 0,67 & 0,34 & 0,53 & 0,19 & 0,15 & 0,15 \\
\hline $\mathrm{Yb}$ & 1,49 & 3,27 & 1,75 & 4,21 & 2,25 & 2,92 & 1,28 & 1,04 & 0,97 \\
\hline $\mathrm{Lu}$ & 0,23 & 0,48 & 0,24 & 0,62 & 0,34 & 0,45 & 0,21 & 0,18 & 0,16 \\
\hline Mo & 0,6 & 0,8 & 0,8 & 1,2 & 1,1 & 1,1 & 1,3 & 1,2 & 1,7 \\
\hline $\mathrm{Ni}$ & 3,5 & 47,7 & 51,3 & 20,5 & 15,4 & 26,1 & 30,7 & 8,9 & 18 \\
\hline As & $<0,5$ & $<0,5$ & $<0,5$ & 0,5 & $<0,5$ & $<0,5$ & $<0,5$ & $<0,5$ & $<0,5$ \\
\hline $\mathrm{Cd}$ & $<0,1$ & $<0,1$ & $<0,1$ & $<0,1$ & $<0,1$ & $<0,1$ & $<0,1$ & $<0,1$ & $<0,1$ \\
\hline $\mathrm{Sb}$ & $<0,1$ & $<0,1$ & $<0,1$ & $<0,1$ & $<0,1$ & $<0,1$ & $<0,1$ & $<0,1$ & $<0,1$ \\
\hline $\mathrm{Bi}$ & $<0,1$ & $<0,1$ & $<0,1$ & $<0,1$ & $<0,1$ & $<0,1$ & $<0,1$ & $<0,1$ & $<0,1$ \\
\hline $\mathrm{Ag}$ & $<0,1$ & $<0,1$ & $<0,1$ & $<0,1$ & $<0,1$ & $<0,1$ & $<0,1$ & $<0,1$ & $<0,1$ \\
\hline $\mathrm{Au}$ & 1,4 & 0,6 & $<0,5$ & $<0,5$ & 1,5 & 2,1 & 1,1 & 1 & $<0,5$ \\
\hline $\mathrm{Hg}$ & $<0,01$ & $<0,01$ & $<0,01$ & $<0,01$ & $<0,01$ & $<0,01$ & $<0,01$ & $<0,01$ & $<0,01$ \\
\hline $\mathrm{Se}$ & $<0,5$ & 0,6 & $<0,5$ & 0,6 & $<0,5$ & 0,7 & $<0,5$ & $<0,5$ & $<0,5$ \\
\hline $\mathrm{Sn}$ & $<1$ & $<1$ & 3 & 2 & 2 & $<1$ & 1 & $<1$ & $<1$ \\
\hline $\mathrm{W}$ & 223,7 & 238,3 & 263,3 & 403,5 & 489,8 & 433,4 & 620,5 & 539,7 & 690,6 \\
\hline
\end{tabular}


as amostras das rochas charnockíticas da Suíte Divino mostram grande variabilidade composicional, de gabróica a granítica (Fig. 3a). A distribuição das amostras no diagrama AFM mostra marcante tendência geoquímica similar a uma suíte cálcio-alcalina expandida (Fig. 3b). No diagrama das séries cálcio-alcalinas apresentam ampla distribuição pelos campos cálcio-alcalino de alto potássio e shoshonítico, à exceção de três amostras (duas básicas e uma ácida) que se situam na série cálcio-alcalina de médio potássio (Fig. 3c). Quanto ao índice de aluminosidade, a maioria das amostras da Suíte Divino é marcantemente metaluminosas, sendo que apenas três delas, dentre trinta e uma, situam-se no campo peraluminoso (Fig. 3d).

Da avaliação conjunta dos diagramas TAS, AFM, séries cálcio-alcalinas e índice de aluminosidade, à luz dos dados petrográficos e de campo, pode-se tirar as seguintes conclusões e sugestões:
- A Suíte Divino representa uma série cálcio-alcalina expandida, metaluminosa, enriquecida em potássio, com composição predominantemente monzonítica a monzogabróica.

- O enriquecimento em potássio pode ser decorrente de um ou mais fatores, tais como: cristalização fracionada, mistura de magmas envolvendo um componente de magma originado com a participação de rochas ricas em potássio (e.g., paragnaisse biotítico) no processo de fusão parcial e/ou contaminação por rochas encaixantes.

- O baixo índice de aluminosidade, juntamente com a assinatura cálcio-alcalina, denota gênese relacionada a magmatismo tipo-I, envolvendo componente máfico (Chappel \& White 2001). Por sua vez, a presença de algumas amostras peraluminosas, que contêm granada em sua composição, indica contaminação por encaixante peraluminosa (e.g., paragnaisse) ou metassoma-
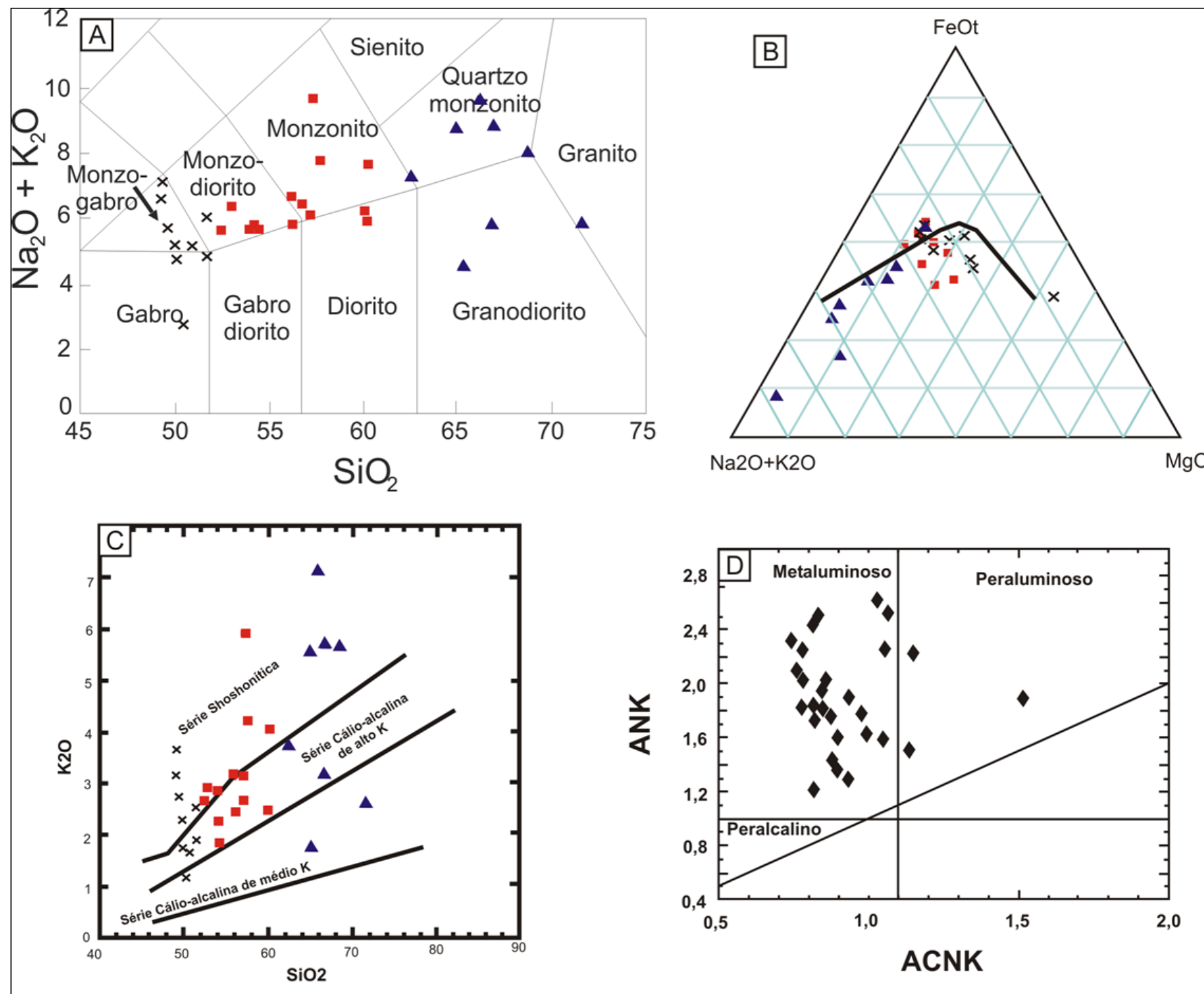

$\times$ Básicos

Intermediários

Figura 3 - Classificação das rochas da Suíte Divino segundo sua composição química. (A) Diagrama TAS (Wilson 1989). (B) Diagrama AFM (Jensen 1976). (C) Diagrama de séries cálcio-alcalinas de (Rickwood 1989 e Le Maitre et al. 1989). (D) Índice de aluminosidade (Shand 1947). 
tismo intramagmático na fase tardia de cristalização. $\mathrm{O}$ aumento de $\mathrm{Al}_{2} \mathrm{O}_{3}$, em meio anídrico, torna possível a formação de granada sobre o ortopiroxênio segundo a reação: $3(\mathrm{Fe}, \mathrm{Mg}) \mathrm{SiO}_{3}$ (ortopiroxênio) $+\mathrm{Al}_{2} \mathrm{O}_{3}$ (do contaminante ou da fusão $)=(\mathrm{Fe}, \mathrm{Mg})_{3} \mathrm{Al}_{2} \mathrm{Si}_{3} \mathrm{O}_{12}$ (granada) Alternativamente, como estas rochas foram submetidas a metamorfismo da fácies granulito, a gênese da granada também pode estar ligada às reações metamórficas relacionadas à quebra de plagioclásio (liberando alumina) em meio anídrico (Frost \& Frost 2008).

Nos diagramas de Harker (Fig. 4) as boas correlações negativas de $\mathrm{Fe}, \mathrm{Ca}, \mathrm{P}, \mathrm{Mg}$, Ti e $\mathrm{V}$ em relação à sílica, evidenciam cristalização fracionada $(\mathrm{Al}, \mathrm{Na}, \mathrm{Ni}$, $\mathrm{Y}, \mathrm{Ba}$ e Sr também apresentam correlações negativas, porém não tão marcantes quantos as primeiras). Potássio apresenta sutil correlação positiva que contrasta com a regularidade do sódio e a marcante correlação negativa do cálcio. Muitos dos padrões observados nos diagramas são similares aos de séries cálcio-alcalinas de arco magmático (Nalini et al. 2000, Pons et al. 2007).

$\mathrm{O}$ diagrama de variação multi-elementar ("aranhograma") mostra que as rochas da Suíte Divino apre- sentam enriquecimento em elementos litófilos de grande raio iônico (LILE, Fig. 5a). Notam-se fortes anomalias negativas de Ti e $\mathrm{P}$, além da anomalia negativa de Th. Os elementos $\mathrm{Nd}$ e $\mathrm{Ta}$ apresentam sutis anomalias, ora positivas, ora negativas. Anomalias negativas de Ti, Ta e $\mathrm{Nb}$ caracterizam associação derivada de magmatismo relacionado à subducção de litosfera oceânica. A anomalia negativa de $\mathrm{Nb}$ e Ti pode significar contaminação do magma mantélico original por componentes crustais, ou ainda processo eficiente de fracionamento do anfibólio (e.g. Martin et al. 1997). A anomalia negativa de $\mathrm{P}$ pode refletir o fracionamento da apatita e/ou plagioclásio.

As curvas de elementos terras raras (Fig. 5b) são muito semelhantes entre si. Todas as amostras apresentam fracionamento similar, ocorrendo leve inclinação para direita, com enriquecimento em terras raras leves e empobrecimento em terras raras pesadas (à exceção da amostra GV-37, que apresenta enriquecimento em terras raras leves e pesadas). As anomalias de Eu são variáveis. Amostras ácidas apresentam predomínio de anomalias positivas. Já as amostras básicas e inter-
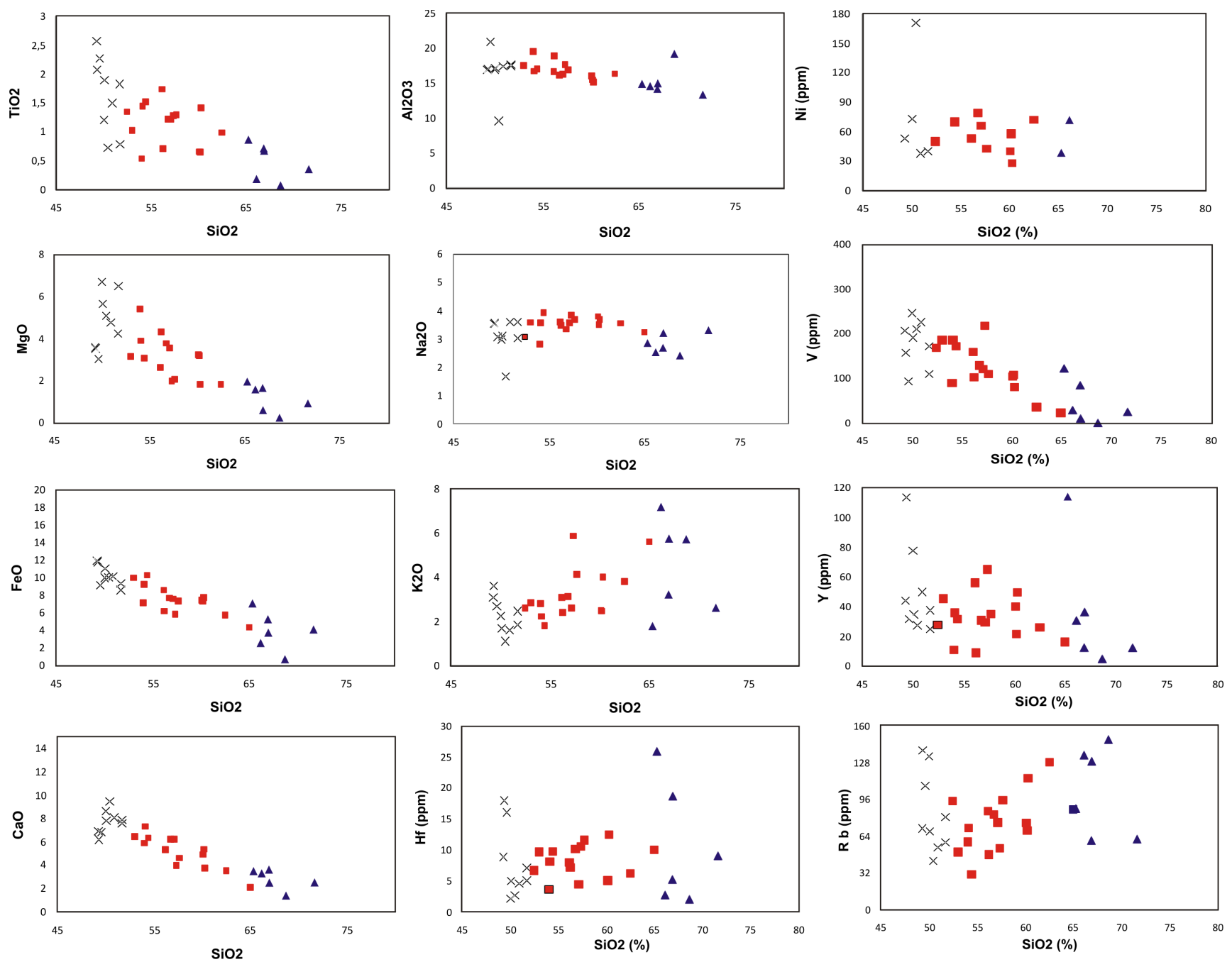

Figura 4 - Diagramas de Harker para elementos maiores e traços das rochas da Suite Divino.Símbolos iguais aos da figura 3. 
mediárias mostram predomínio de anomalias negativas de Eu. Esta variabilidade indica diferentes estágios de fusão parcial, provavelmente relacionados a percentuais variados de mistura das diferentes fontes e/ou à retenção de fases minerais distintas na fonte (Rollinson 1993, Duarte et al. 1999, Valladares et al. 2000). O empobrecimento de elementos terras raras pesados em relação às terras raras leves observada na maior parte das análises indica fonte mantélica com granada residual, fusão parcial de crosta inferior e/ou precipitação de granada em porção profunda do magma. A hornblenda (oriunda da uralitização dos piroxênios) também contribui para o enriquecimento em elementos terras raras leves em relação aos pesados (Rollinson 1993).

$\mathrm{O}$ diagrama da figura $6 \mathrm{~A}$ mostra que os charnockítos sofreram perda de tório e chumbo, o que é característico de rochas que sofreram metamorfismo.
O diagrama da figura 6B indica que este metamorfismo atingiu a fácies granulítica, em concordância com a análise petrográfica.

As rochas da Suíte Divino apresentam grande dispersão na maioria dos diagramas discriminatórios de ambiente tectônico (Fig. 7), caindo nos campos dos granitóides de arco, intraplaca, pós-colisinais e de granitóides de margem continental ativa. Vale ressaltar que diagramas discriminantes muitas vezes refletem mais os processos sofridos pela rocha do que seu ambiente petrogenético propriamente dito. Ou seja, os efeitos da cristalização fracionada, mistura de magmas e mobilidade química dos elementos são responsáveis pela ambigüidade dos resultados.

Química Mineral Minerais constituintes dos charnockitos, como ortopiroxênio e clinopiroxênio, são
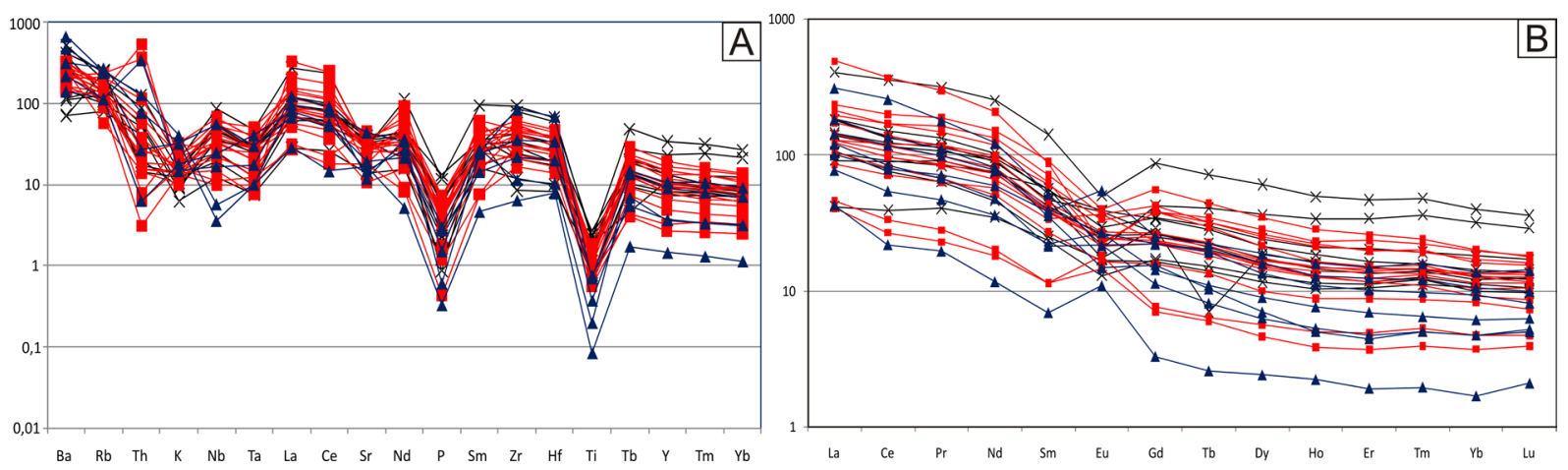

Figura 5 - (A) Diagrama de variação multi-elementar discriminado quanto ao teor em sílica e normalizados para o manto primitivo (Taylor \& McLennan 1985; para P normalização segundo Sun 1980). (B) Padrões de elementos terras raras normalizados para condrito (Taylor \& Mclennan 1985). Símbolos iguais aos da figura 3.
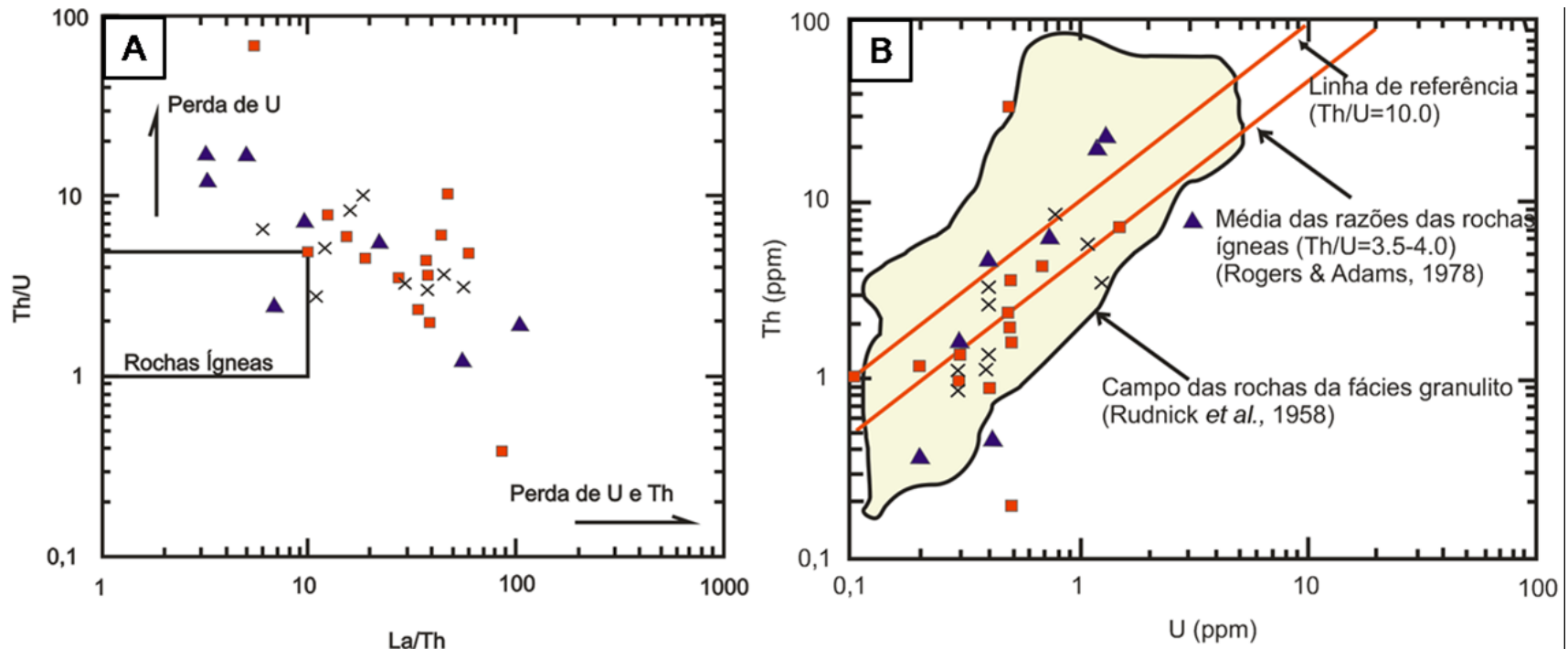

Figura 6 - (A) Diagrama Th/Ux La/Th discriminado quanto ao teor em sílica (Rudnick et al. 1985). (B) Diagrama Th $x$ U discriminado quanto ao teor em sílica (Rudnick et al. 1985). Símbolos iguais aos da figura 3. 

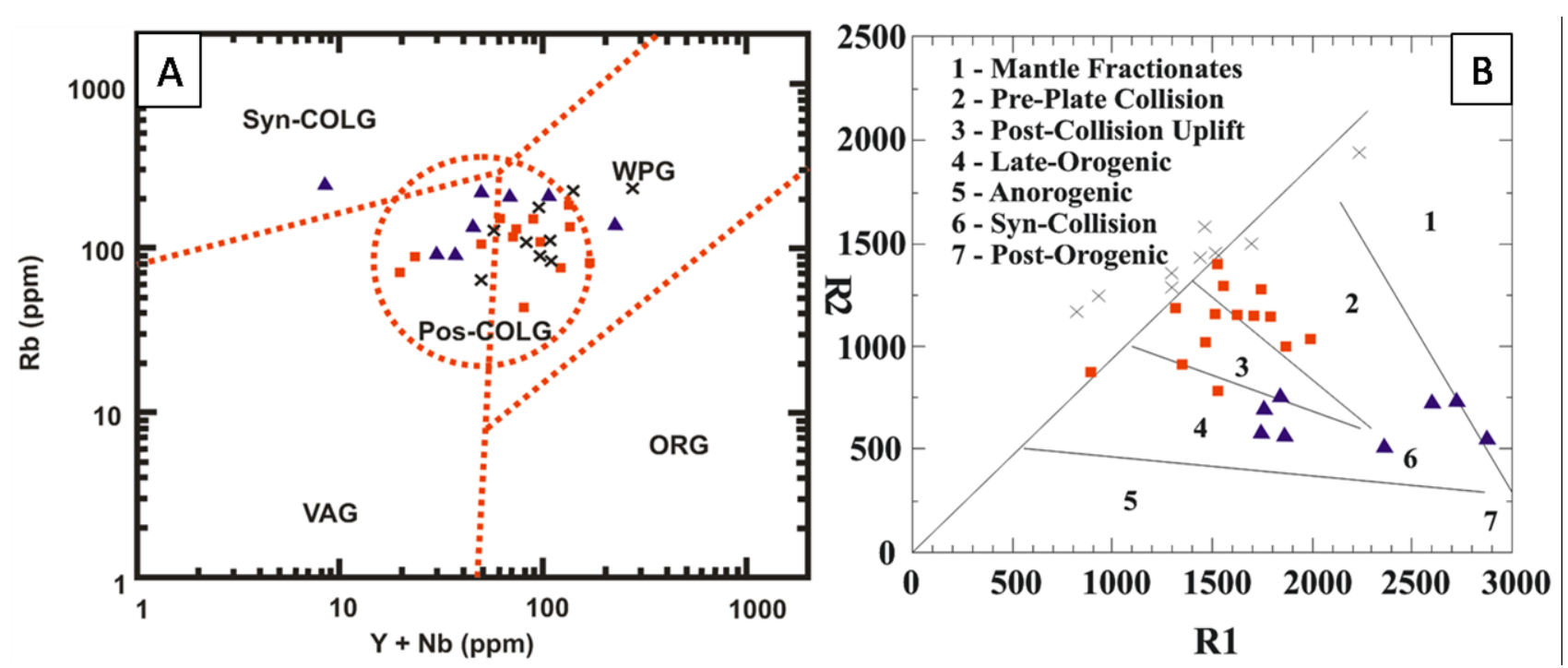

Figura 7 - Diagramas discriminatórios de ambiente tectônico. A) Diagrama Rb $x Y+N b$ (Pearce et al. 1984 com dominios tectônicos de Pearce 1996). (B) Diagrama R1 x R2 (Rogers \& Adams 1978). Simbolos iguais aos da figura 3.

ótimos calibradores de temperatura. Análises de sua química mineral trazem, portanto, informações sobre os processos ígneos e metamórficos que ocorreram nas grandes profundidades crustais características destas rochas. As microanálises foram realizadas no Laboratório de Microanálises da UFMG, utilizando-se aparelho de microssonda eletrônica da marca JEOL, modelo JXA-8900RL. Os minerais analisados foram orto e clinopiroxênios, sendo obtida uma a três análises pontuais para cada cristal. A definição do local de cada análise foi realizada segundo a seguinte rotina: (i) identificação dos elementos presentes em cada mineral por meio do detector EDS (Energy Dispersive X-Ray Spectrometer); (ii) aquisição de imagens de elétrons secundários e retroespalhados, com resolução de alguns nanômetros, visando à observação de possíveis zonamentos químicos, exsoluções e/ou intercrescimento de fases minerais distintas; (iii) obtenção das microanálises. Os elementos analisados para todos os minerais foram $\mathrm{Si}, \mathrm{Ti}, \mathrm{Al}$, $\mathrm{Fe}, \mathrm{Mn}, \mathrm{Mg}, \mathrm{Ca}, \mathrm{Na}, \mathrm{K}$ e Cr. Os padrões utilizados estão relacionados na tabela 2 . O programa de correção de dados empregado foi ZAF. As fórmulas estruturais foram calculadas com base na exigência de seis cargas negativas da rede estrutural para os piroxênios.

INTERPRETAÇÃO DOS DADOS Os piroxênios ocorrem em diversas proporções nas rochas da Suíte Divino. Foram analisados nove cristais de piroxênio, cinco de clinopiroxênio e quatro de ortopiroxênio. Os dados são apresentados na tabela 3. Quanto à composição, os piroxênios analisados agruparam-se em duas regiões do diagrama (Fig. 8). As análises com maior teor em $\mathrm{CaO}$, correspondentes aos cristais de clinopiroxênio, concentram-se nos campos da salita e augita. As análises pobres em $\mathrm{CaO}$, correspondentes aos cristais de ortopiroxênio, agrupam-se no setor do hiperstênio. Duas análises (R5-C9-CP-2 e T15-C7-OP-3; Fig. 8)
Tabela 2 - Elementos analisados e padrões utilizados para química mineral em microssonda eletrônica. Todos os padrões são da Coleção Ian Steele com exceção do rutilo que é da Coleção Astimex. Os resultados analíticos são expressos na forma de óxidos. Segundo padrão da microssonda JEOL modelo JXA-8900RL todo ferro obtido é expresso como $\mathrm{Fe}^{2+}$. Para o alumínio foram utilizados dois padrões, anortita sintética para o feldspato potássico e óxido de aluminio $\left(\mathrm{Al}_{2} \mathrm{O}_{3}\right)$ para os demais minerais.

\begin{tabular}{|c|c|}
\hline ELEMENTO & PADRÃO \\
\hline $\mathrm{Na} 2 \mathrm{O}$ & Jadeita \\
\hline $\mathrm{K} 2 \mathrm{O}$ & Microclina Asbestos \\
\hline $\mathrm{Cr} 2 \mathrm{O} 3$ & Óxido de Cromo (Cr2O3) \\
\hline $\mathrm{MgO}$ & Óxido de Magnésio (MgO) \\
\hline $\mathrm{CaO}$ & Anortita Sintética \\
\hline $\mathrm{MnO}$ & Mn-Hortonolita \\
\hline $\mathrm{Al} 2 \mathrm{O} 3$ & $\begin{array}{l}\text { Óxido de Alumínio (Al2O3) / Anortita } \\
\text { Sintética }\end{array}$ \\
\hline $\mathrm{TiO} 2$ & Rutilo \\
\hline $\mathrm{FeO}$ & Magnetita \\
\hline $\mathrm{SiO} 2$ & Quartzo \\
\hline
\end{tabular}

apresentaram composição discrepante das demais. São análises de bordas de cristais, possivelmente alteradas.

O diagrama da figura 9 traça isotermas para a temperatura de cristalização de piroxênios provenientes de charnockitos de diversas partes do mundo (Frost \& Frost 2008). As análises de piroxênio obtidas neste trabalho são semelhantes àquelas da Suíte Utsalik (Quebec, Canadá). Os dados indicam temperatura em torno de $775-800{ }^{\circ} \mathrm{C}$. Para as análises de borda de cris- 
Tabela 3 - Resultados das análises de química mineral em cristais de piroxênios dos charnockitos.

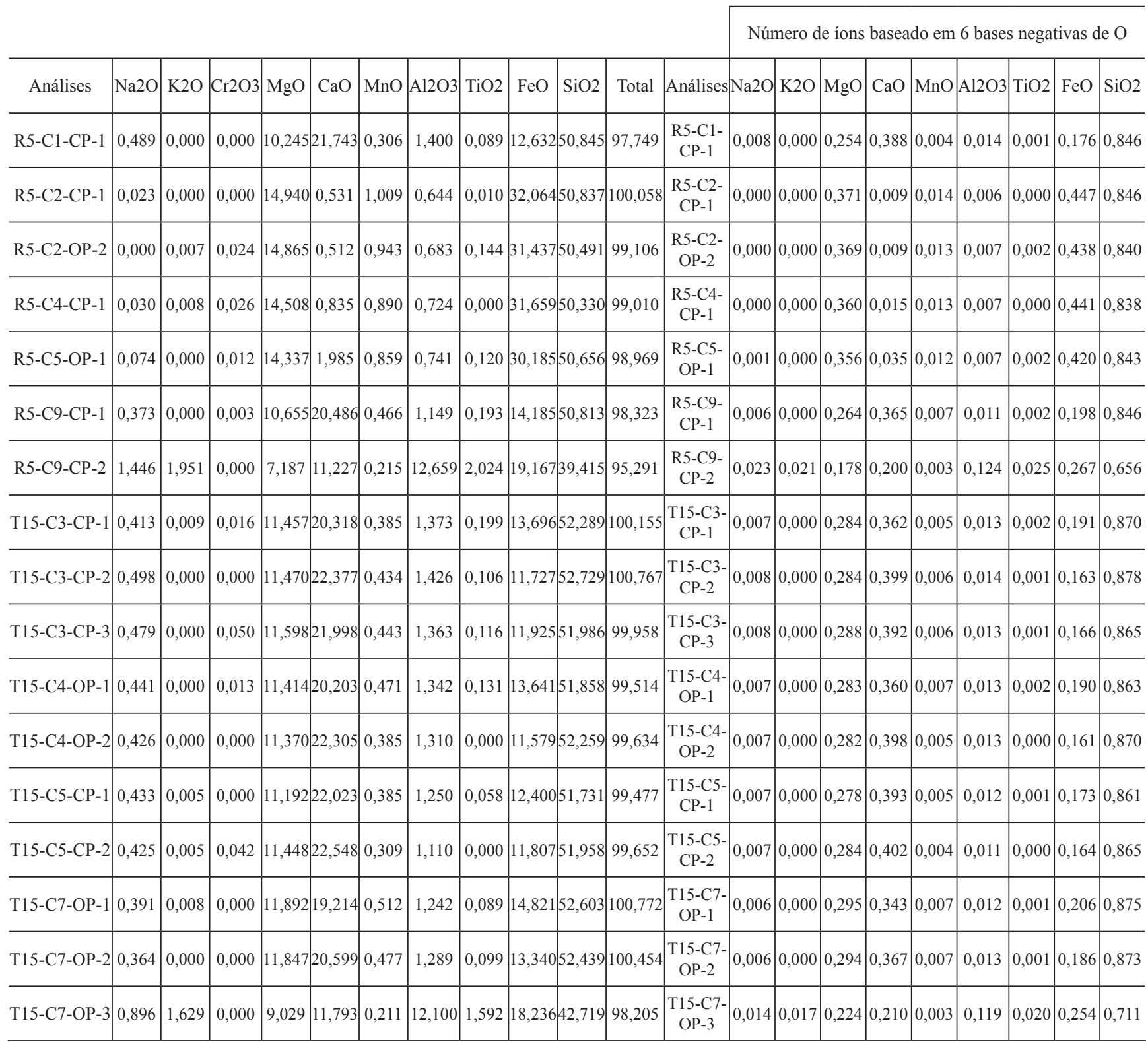

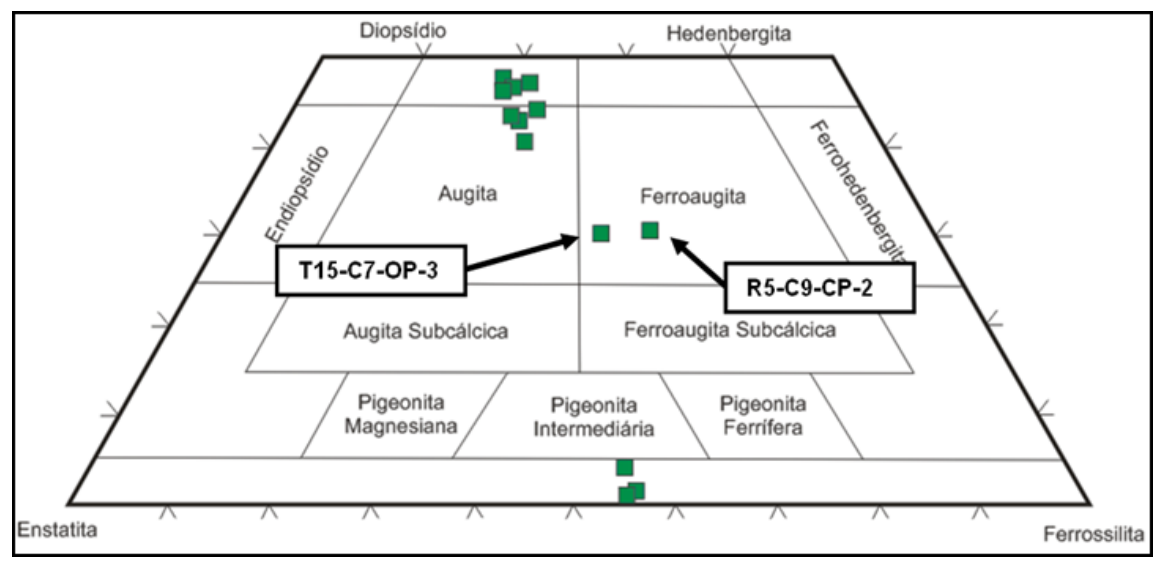

Figura 8 - Diagrama composicional para análise química mineral em cristais de piroxênio. 


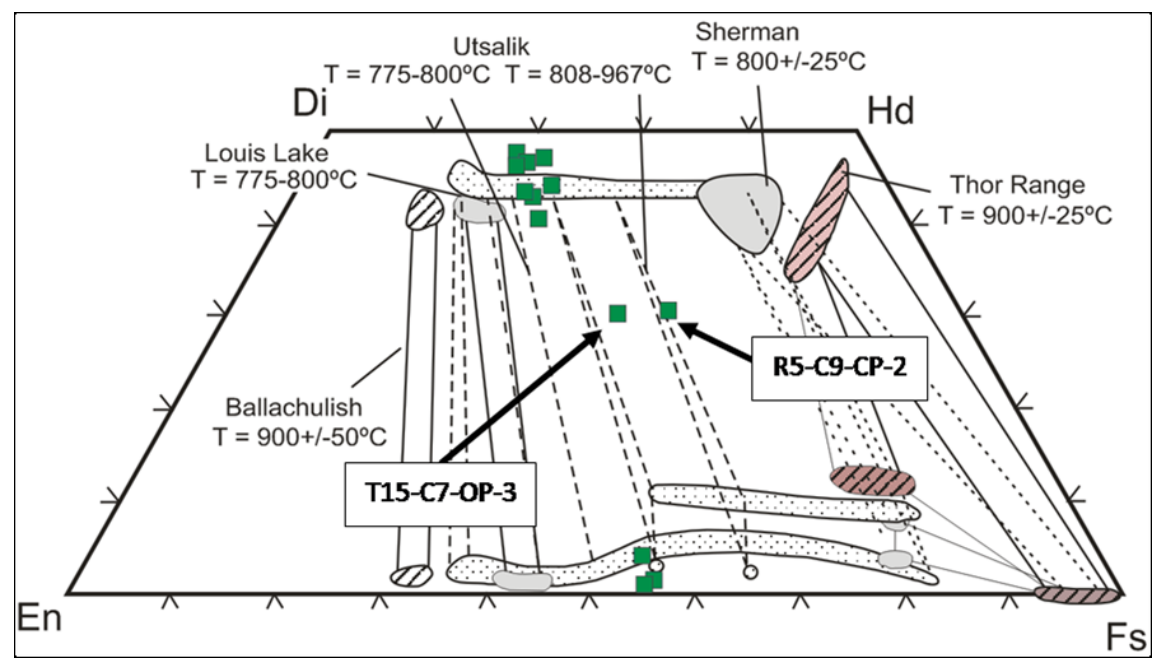

Figura 9 - Diagrama composicional para análise química mineral em cristais de piroxênio dos charnockitos da Suite Divino (quadrados) e algumas suites charnockiticas do mundo (Frost \& Frost 2008).

tal os valores são de 808 a $967^{\circ} \mathrm{C}$ (R5-C9-CP-2 e T15C7-OP-3; Fig. 9), podendo representar recristalização metamórfica na fácies granulito. Este tipo de análise (apesar de bem ilustrativo) é, porém, pouco preciso. Para um cálculo geotermométrico mais minucioso foi utilizado o programa PTmafic (2.0), que aborda a metodologia descrita por Brey \& Köhler (1990) com número de íons baseado em seis cargas negativas de oxigênio. A temperatura obtida para análises realizadas no centro dos cristais de piroxênio foi de $1007 \pm 26^{\circ} \mathrm{C}$ (assumida como temperatura de cristalização magmática), e a temperatura obtida para análises realizadas na borda dos cristais foi de $741 \pm 26^{\circ} \mathrm{C}$ (considerada a temperatura de estabilidade para o metamorfismo granulítico).

Geocronologia U-Pb (LA-ICPMS) Os grãos de zircão para as análises U-Pb foram selecionados a partir de concentrados de minerais pesados, obtidos pelos meios usuais de britagem, moagem, concentração em bateia e separação magnética. Todos os cristais de zircão foram montados em seção circular de araldite com $2,5 \mathrm{~cm}$ de diâmetro e polidos até que zircões ficassem expostos. Imagens foram obtidas com utilização de microscópio ótico (Leica MZ $12_{5}$ ) e microscópio electrônico de varredura (Jeol JSM 5800). Os grãos de zircão foram datados com Microssonda a Laser (New Wave UP213) acoplado a um MC-ICP-MS (Neptune), no Laboratório de Geologia Isotópica da UFRG. Dados isotópicos foram adquiridos pelo modo estático com tamanho do feixe Laser de 15 a 25 um. Fracionamentos de elementos por indução do Laser e discriminação de massa instrumental foram corrigidos com a utilização de padrão de referência de zircão (GJ-1) (Simon et al. 2004). Erros externos foram calculados com a propagação do erro das medidas individuais do padrão GJ-1 e das medidas individuais de cada amostra de zircão (ou spot). No tratamento dos dados isotópicos e cálculo da idade utilizou-se o programa ISOPLOT-Ex (Ludwig
2001). Os desvios das razões isotópicas são de $1 \sigma$.

RESULTADOS U-Pb Foram datadas duas amostras de charnockitos da Suíte Divino, ambos de composição monzodiorítica. Embora apresentem aspecto macroscópico maciço, o estudo em lâmina delgada revela o desenvolvimento da foliação regional.

Amostra TJ-46 Apresenta população de zircão bastante homogênea, composta por prismas com razão comprimento/largura variando de 2:1 a 3:1, límpidos e incolores. Foram obtidas 34 análises de spot em 34 grãos de zircão (Tab. 4 e Fig. 10a). Um núcleo herdado (27) e dois xenocristais (43 e 44) foram identificados; um destes últimos possui idade mínima em torno de $2000 \mathrm{Ma}$. Os cristais restantes exibem zoneamento oscilatório em imagem BSE e razões $\mathrm{Th} / \mathrm{U}$ elevadas, típicas de cristais de zircão magmáticos. No diagrama concórdia, as análises se dispõem em um arranjo grosseiramente colinear indicando um processo complexo de perda de $\mathrm{Pb}$. Assumindo que a perda de $\mathrm{Pb}$ foi menos significativa para aqueles seis spots cujas idades ${ }^{238} \mathrm{U}_{-} \mathrm{Pb}^{206}$ são as mais elevadas (34 a 39), foi calculada idade concórdia em $592 \pm 7$ Ma $(2 \sigma)$, interpretada como a melhor estimativa para a idade de cristalização magmática do charnockito.

Amostra T-16 A população de zircão era igualmente muito homogênea e composta por prismas com razão comprimento/largura variando de 2:1 a 3:1. Os grãos não apresentavam núcleos herdados e zoneamento oscilatório pode ser observado em algumas imagens BSE. Foram datados 33 spots em 33 cristais (Tab. 4 e Fig. 10b), sendo que todos os grãos de zircão apresentaram razões $\mathrm{Th} / \mathrm{U}$ elevadas, típicas de zircões de origem magmática. As análises são concordantes a pouco discordantes, e desenham no diagrama concórdia um arranjo aproximadamente linear, semelhante ao observado para a amostra anterior. A interpretação dos dados seguiu a mesma linha, sendo calculada uma idade concórdia para os 16 
Tabela 4 - Resultados analiticos U-Pb.

\begin{tabular}{|c|c|c|c|c|c|c|c|c|c|c|c|c|c|c|c|c|c|c|c|}
\hline & \multicolumn{5}{|c|}{ Concordia 1} & \multicolumn{5}{|c|}{ Concordia 2} & \multicolumn{6}{|c|}{ Age (Ma) } & \multicolumn{3}{|c|}{$\%$} \\
\hline & ${ }^{207} \mathrm{~Pb}^{* / 2}{ }^{235} \mathrm{U}$ & \pm & ${ }^{6} \mathrm{~Pb} * / 238 \mathrm{U}$ & \pm & Rho 1 & ${ }^{238} \mathrm{U} /{ }^{206} \mathrm{~Pb}$ & \pm & ${ }^{207} \mathrm{~Pb} /{ }^{206} \mathrm{~Pb}$ & \pm & Rho 2 & $\mathrm{~b} /{ }^{238} \mathrm{U}$ & \pm & ${ }^{207} \mathrm{~Pb} /{ }^{235} \mathrm{U}$ & \pm & ${ }^{207} \mathrm{~Pb} /{ }^{206} \mathrm{~Pb}$ & \pm & & Disc. & f 206 \\
\hline r 7 ( & & 3,05 & 1 & 0,96 & 0,31 & ,23414 & 0,96 & 05860 & 2,90 & 0,33 & 50 & & 550 & 17 & 552 & 1 & 86 & 0 & 00 \\
\hline $\mathrm{Zr} 8$ & 67 & 1,96 & 085 & 99 & 0,5 & ,70530 & 0,99 & 0,05751 & 1,69 & 0,5 & 28 & & 525 & 10 & 511 & & 89 & -3 & 000 \\
\hline Zr 9 & 19 & 1,48 & 0,08 &, 74 & 0,50 & ,47750 & 0,74 & 05812 & 1,29 & 0 , & 539 & & 538 & & 33 & & 86 & -1 &, 000 \\
\hline 10 & 6605 & 1,27 & 843 & 0,94 & 0,74 & ,86278 & 0,94 & 0,05731 & 0,85 & 1 , & 522 & 5 & 51 & 7 & 503 & & 31 & -4 & 0,00 \\
\hline ) & 71639 & 2,52 & 7 & 1,10 & 0,44 & 34211 & 1,10 & 05893 & 2,26 & 0 , & 545 & 6 & 549 & 14 & 56 & 13 & 68 & 4 & 00 \\
\hline ) & 2762 & 2,02 & 0,08916 & 1,38 & 0,69 & ,21539 & 1,38 & 05919 & 1,47 & 0,94 & 551 & 8 & 555 & 11 & 57 & 8 & 94 & 4 & 0,00 \\
\hline Zr 13 & 65820 & 1,28 & 0833 & 0,87 & 0,68 & ,00231 & 0,87 & 0,05730 & 0,94 & 0,92 & 516 & 4 & 514 & 7 & 503 & 5 &, 93 & -3 & 0,000 \\
\hline 6) & 68 & 2,01 & 0,09090 & 1,35 & 0,67 & 00055 & 1,35 & 05917 & 1,49 & 0,90 & 561 & 8 & 563 & 11 & 57 & 9 &, 02 & 2 & 0,0006 \\
\hline $\mathrm{Zr} 15$ & 4163 & 1,43 & 822 & 0,82 & 0,58 & 17119 & 0,82 & 0,05664 & 1,16 & 0,71 & & 4 & 503 & 7 & 47 & 6 & ,95 & -7 & 0,001 \\
\hline Zr 16 & 7768 & 1,44 & 0,0861 & 1,13 & 0,78 & ,61994 & 1,13 & 05711 & 0,90 & 1,26 & 532 & 6 & 525 & 8 & 496 & 4 & 88 & -7 & 0,000 \\
\hline 46) & 3584 & 1,50 & 08 & 1,20 & 0,80 & 60213 & 1,20 & 05771 & 0,91 & 1,31 & & 6 & 53 & 8 & 51 & & 42 & -3 & 0,00 \\
\hline 46) & 2753 & 2,30 & 0,08943 & 10 & 0,48 & 189 & 1,10 & 05900 & 2,02 & 0,55 & & & 55 & 13 & 567 & 11 & 28 & 3 & 0,00 \\
\hline 6) & 5305 & 2,61 & 0,09259 & 1,36 & 0,52 & 80001 & 1,36 & 05899 & 2,23 & 0 , & 571 & 8 & 570 & 15 & 567 & 13 & 83 & -1 & 0,00 \\
\hline 46) & 77 & 1,31 & 828 & 0,93 & 0 , & 250 & 0,93 & 05654 & 0,92 & 1,01 & 513 & & 50 & 7 & 474 & 4 & 96 & -8 & 0,00 \\
\hline ) & 0,65472 & 1,38 & 2828 & 1,06 & 0,76 & 606 & 1,06 & 68 & 0,89 & & & & 511 & 7 & 479 & 4 & 50 & -8 & 0,000 \\
\hline 46) & 2756 & 2,08 & 8953 & 1,03 & 0,49 & 16949 & 1,03 & 05894 & 1,81 & 0,57 & 553 & 6 & 555 & 12 & 565 & 10 & 04 & 2 & 0,000 \\
\hline 46) & 8934 & 2,53 & & 1,80 & 0,71 & 62312 & 1,80 & 11 & 1,77 & 2 & 2 & 10 & 532 & 13 & 53 & 9 & 56 & 0 & 00 \\
\hline 46) & 0,74184 & 3,03 & & 05 & 0,35 & 99927 & 1,05 & 18 & 2,84 & $c^{\circ}$ & 561 & 6 & 563 & 17 & 57. & 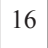 & 23 & 2 & 00 \\
\hline $\mathrm{Zr} 25$ & 2451 & 2,09 & 0,08885 & 08 & 0,52 & ,25554 & 1,08 & 05914 & 1,79 & 0,60 & 9 & I & 553 & 12 & 572 & 10 & 12 & 4 & 0,000 \\
\hline Zr 26 & 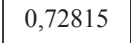 & ,24 & 2 & 7 & 0,46 & 19597 & 1,97 & 13 & 3,76 & 0 & 552 & 11 & 5 & 24 & 572 & 21 & 5 & 4 & 00 \\
\hline 10 & 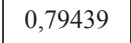 & 2,28 & . & 4 & 0,41 &, 77743 & 0 & & 2,08 & & & 5 & 594 & 14 & 677 & 14 & ,03 & 16 & 0 \\
\hline & 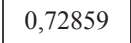 & | & $x^{-1}$ & 0,85 & 0,27 & 34210 & 0 & 0,05993 & 3,04 & & & 5 & 556 & 18 & 601 & 18 & & 9 & 0,001 \\
\hline & 0,71484 & $2,4 \mathrm{~J}$ & 0,08763 & 1 & 0 & & 1 & & 13 & & & $r^{\prime}$ & & 13 & & 12 & & 6 & \\
\hline o & TOT & 1,36 & 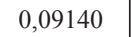 & 0,74 & 0,54 & 1140 & 0,74 & 0,05939 & 1,14 & & & & & & & & & 3 & \\
\hline-46$)$ & 73003 & 1,97 & 0,00003 & 1,17 & 0,59 & ,28349 & 1,17 & 05974 & 1,58 & 0,7 & & & J & 11 & r & & 00 & 8 & 0,00 \\
\hline -46) & 4119 & 1,76 & 8977 & 1,21 & 0,69 & , 13957, & 1,21 & 05988 & 1,29 & 0,94 & 54 & & 563 & 10 & 599 & & 67 & 8 & 0,00 \\
\hline-46$)$ & 80638 & 2,11 & 09712 & 0,94 & 0,45 & ,29697 & 0,94 & 06022 & 1,89 & 0,5 & & & 60 & 13 & 612 & 12 & 49 & 2 & 0,00 \\
\hline -46) & 1677 & 1,81 & 0,09820 & 0,81 & 0,45 &, 18288 & 0,81 & 06032 & 1,62 & 0,5 & 604 & & 606 & 11 & 61 & 10 & 87 & 2 & 0,0 \\
\hline Zr 36 (TJ-46) & 0,78199 & 2,25 & 9513 & 0,98 & 0,43 & 51209 & 0,98 & 62 & 03 & 0 , & 586 & & 587 & 13 & 590 & 12 & 42 & 1 & 0,0 \\
\hline-1 & 年 & {$[2,00$} & 年 & 13 & 0,55 & 0,72616 & 1,13 & & 72 & 0,66 & & I0 & - & 12 & 10 & 11 & 30 & 7 & 0,000 \\
\hline $510(10) 0)$ & 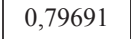 & $\mid 1,74$ & , & 0,99 & 0,51 & 10,39201 & 0,99 & 0,00000 & 1,67 & 0,60 & & 10 & 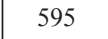 & 12 & 00 & 10 & 40 & 2 & 0,0008 \\
\hline 年 & 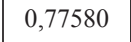 & 2,91 & 09401 & 1,48 & 0,51 &, 62995 & 1,48 & 0,05981 & 2,51 & 0,59 & (2) & F & (2) & 17 & 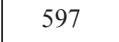 & 15 & 10 & 3 & 0,0024 \\
\hline $43(1 J-46)$ & 5,97379 & 1,65 & 0,34238 & 0,86 & 0,52 & 2,92076 & 0,86 & 3 & 1,41 & 0,61 & 1898 & 16 & 191. & 33 & 2051 & 29 &, 36 & 7 & 0,00 \\
\hline 44 (TJ-46) & 0466 & 05 & 20405 & 0,47 & 0,08 & 90064 & 0,47 & 0,10679 & 6,03 & 0,08 & 1197 & 6 & 1409 & dJ & 1745 & 105 & 0,13 & Disc. & 0,0006 \\
\hline
\end{tabular}

spots que são praticamente concordantes e guardam as idades ${ }^{238} \mathrm{U}_{-} \mathrm{Pb}^{206}$ mais elevadas. A idade obtida, $603 \pm 4$ $\mathrm{Ma}$, é interpretada como a melhor aproximação para a idade de cristalização magmática da rocha.
O fato das duas idades serem concordantes na margem de erro reforça a interpretação adotada para os dados analíticos, permitindo assumir que os corpos charnockíticos foram gerados em torno de $600 \mathrm{Ma}$. Os 


\section{Tabela 4 - Continuação}

\begin{tabular}{|c|c|c|c|c|c|c|c|c|c|c|c|c|c|c|c|c|c|c|c|}
\hline \multirow{2}{*}{$\begin{array}{l}\text { T-16 } \\
\text { Spot }\end{array}$} & \multicolumn{7}{|c|}{ Ratios } & \multicolumn{6}{|c|}{ Age (Ma) } & \multirow{2}{*}{$\begin{array}{c}232 \mathrm{Th} / \\
{ }^{238} \mathrm{U}\end{array}$} & \multirow{2}{*}{$\mid \begin{array}{c}\% \\
\text { Disc. }\end{array}$} & \multirow{2}{*}{ f 206} & \multirow{2}{*}{ Th ppm } & \multirow{2}{*}{$\mathrm{U}$ ppm } & \multirow{2}{*}{$\begin{array}{c}\mathrm{Pb} \\
\mathrm{ppm}\end{array}$} \\
\hline & ${ }^{207} \mathrm{~Pb}^{* / 235} \mathrm{U}$ & \pm & ${ }^{206} \mathrm{~Pb}^{*} /{ }^{238} \mathrm{U}$ & \pm & Rho 1 & $\begin{array}{l}{ }^{207} \mathrm{~Pb}^{* /} \\
{ }^{206} \mathrm{~Pb}^{*}\end{array}$ & \pm & \begin{tabular}{|c|}
${ }^{206} \mathrm{~Pb} /$ \\
${ }^{238} \mathrm{U}$
\end{tabular} & \pm & $\begin{array}{l}{ }^{207} \mathrm{~Pb} / \\
{ }^{235} \mathrm{U}\end{array}$ & \pm & \begin{tabular}{|l|}
${ }^{207} \mathrm{~Pb} /$ \\
${ }^{206} \mathrm{~Pb}$
\end{tabular} & \pm & & & & & & \\
\hline $\mathrm{Zr}-1$ (T-16) & 0,81133 & 3,89 & 0,09901 & 1,09 & 0,28 & 0,05943 & 3,74 & 609 & 7 & 603 & 23 & 583 & 22 & 1,23 & -4 & 0,0014 & 86,70 & 71,22 & 9,20 \\
\hline $\mathrm{Zr}-2(\mathrm{~T}-16)$ & 0,81403 & 2,85 & 0,09901 & 1,09 & 0,38 & 0,05963 & 2,63 & 609 & 7 & 605 & 17 & 590 & 16 & 0,59 & -3 & 0,0015 & 29,53 & 50,07 & 6,18 \\
\hline Zr-3 (T-16) & 0,84372 & 3,41 & 0,10188 & 1,04 & 0,30 & 0,06006 & 3,25 & 625 & 6 & 621 & 21 & 606 & 20 & 0,47 & -3 & 0,0010 & 34,36 & 73,62 & 8,56 \\
\hline Zr-4 (T-16) & 0,81375 & 3,57 & 0,09931 & 1,33 & 0,37 & 0,05943 & 3,31 & 610 & 8 & 605 & 22 & 583 & 19 & 1,15 & -5 & 0,0023 & 75,19 & 65,66 & 8,90 \\
\hline Zr-5 (T-16) & 0,81646 & 3,67 & 0,09835 & 1,20 & 0,33 & 0,06021 & 3,46 & 605 & 7 & 606 & 22 & 611 & 21 & 0,46 & 1 & 0,0019 & 35,54 & 77,93 & 8,89 \\
\hline Zr-6 (T-16) & 0,77768 & 3,34 & 0,09477 & 1,12 & 0,34 & 0,05951 & 3,14 & 584 & 7 & 584 & 19 & 586 & 18 & 0,62 & 0 & 0,0014 & 31,90 & 52,20 & 6,26 \\
\hline $\mathrm{Zr}-7$ (T-16) & 0,78462 & 3,26 & 0,09562 & 1,18 & 0,36 & 0,05951 & 3,04 & 589 & 7 & 588 & 19 & 586 & 18 & 1,33 & 0 & 0,0014 & 155,36 & 118,07 & 14,71 \\
\hline $\mathrm{Zr}-8(\mathrm{~T}-16)$ & 0,75565 & 3,58 & 0,09047 & 1,19 & 0,33 & 0,06058 & 3,38 & 558 & 7 & 571 & 20 & 624 & 21 & 1,03 & 11 & 0,0034 & 56,89 & 55,75 & 7,37 \\
\hline Zr-9 (T-16) & 0,76997 & 3,83 & 0,09314 & 1,01 & 0,26 & 0,05996 & 3,70 & 574 & 6 & 580 & 22 & 602 & 22 & 0,90 & 5 & 0,0022 & 50,89 & 57,25 & 7,26 \\
\hline $\mathrm{Zr}-10(\mathrm{~T}-16)$ & 0,79191 & 3,46 & 0,09567 & 1,29 & 0,37 & 0,06003 & 3,21 & 589 & 8 & 592 & 20 & 605 & 19 & 0,67 & 3 & 0,0016 & 38,18 & 57,46 & 7,88 \\
\hline $\mathrm{Zr}-11$ (T-16) & 0,74504 & 3,30 & 0,09043 & 0,95 & 0,29 & 0,05975 & 3,16 & 558 & 5 & 565 & 19 & 595 & 19 & 0,47 & 6 & 0,0023 & 37,73 & 80,73 & 9,34 \\
\hline $\mathrm{Zr}-12(\mathrm{~T}-16)$ & 0,80258 & 3,15 & 0,09642 & 2,30 & 0,73 & 0,06037 & 2,15 & 593 & 14 & 598 & 19 & 617 & 13 & 0,78 & 4 & 0,0014 & 60,33 & 78,38 & 9,98 \\
\hline $\mathrm{Zr}-13(\mathrm{~T}-16)$ & 0,79411 & 2,86 & 0,09591 & 0,88 & 0,31 & 0,06005 & 2,72 & 590 & 5 & 593 & 17 & 605 & 16 & 1,56 & 2 & 0.0015 & 184,70 & 119,40 & 17,63 \\
\hline Zr-14 (T-16) & 0,78134 & 3,77 & 0,09509 & 1,18 & 0,31 & 0,05960 & 3,58 & 586 & 7 & 586 & 22 & 589 & 21 & 1,11 & 1 & 0,0035 & 65,09 & 59,04 & 7,31 \\
\hline $\mathrm{Zr}-15(\mathrm{~T}-16)$ & 0,76239 & 3,03 & 0,09247 & 1,09 & 0,36 & 0,05979 & 2,83 & 570 & 6 & 575 & 17 & 596 & 17 & 0,43 & 4 & 0,0017 & 43,85 & 103,21 & 12,06 \\
\hline $\mathrm{Zr}-16(\mathrm{~T}-16)$ & 0,74674 & 2,86 & 0,09160 & 1,63 & 0,57 & 0,05912 & 2,35 & 565 & 9 & 566 & 16 & 572 & 13 & 0,85 & 1 & 0,0011 & 64,65 & 76,52 & 10,64 \\
\hline $\mathrm{Zr}-17$ (T-16) & 0,77875 & 2,80 & 0,09500 & 1,36 & 0,48 & 0,05945 & 2,45 & 585 & 8 & 585 & 16 & 584 & 14 & 0,60 & 0 & 0,0013 & 41,80 & 69,92 & 9,82 \\
\hline $\mathrm{Zr}-18$ (T-16) & 0,76065 & 2,84 & 0,09304 & 1,39 & 0,49 & 0,05929 & 2,48 & 574 & 8 & 574 & 16 & 578 & 14 & 0,76 & 1 & 0,0009 & 54,32 & 72,27 & 9,50 \\
\hline Zr-19 (T-16) & 0,77337 & 2,34 & 0,09362 & 1,23 & 0,53 & 0,05991 & 1,99 & 577 & 7 & 582 & 14 & 600 & 12 & 0,66 & 4 & 0,0006 & 96,60 & 147,13 & 18,89 \\
\hline $\mathrm{Zr}-20(\mathrm{~T}-16)$ & 0,79567 & 2,71 & 0,09643 & 1,61 & 0,60 & 0,05984 & 2,17 & 593 & 10 & 594 & 16 & 598 & 13 & 0,76 & 1 & 0,0005 & 55,13 & 73,43 & 9,95 \\
\hline $\mathrm{Zr}-21(\mathrm{~T}-16)$ & 0,73864 & 2,04 & 0,09052 & 0,97 & 0,48 & 0,05918 & 1,79 & 559 & 5 & 562 & 11 & 574 & 10 & 1,31 & 3 & 0,0007 & 191,16 & 146,74 & 19,97 \\
\hline $\mathrm{Zr}-22(\mathrm{~T}-16)$ & 0,77718 & 2,84 & 0,09519 & 1,24 & 0,44 & 0,05921 & 2,56 & 586 & 7 & 584 & 17 & 575 & 15 & 0,58 & -2 & 0,0008 & 50,83 & 5,86 & 9,85 \\
\hline $\mathrm{Zr}-23(\mathrm{~T}-16)$ & 0,75783 & 2,87 & 0,09298 & 1,01 & 0,35 & 0,05912 & 2,69 & 57 & 6 & 573 & 16 & 571 & 15 & 0,68 & -1 & 0,0009 & 103,78 & 10,24 & 18,02 \\
\hline $\mathrm{Zr}-24(\mathrm{~T}-16)$ & 0,76167 & 2,72 & 0,09332 & 0,99 & 0,36 & 0,05919 & 2,54 & 575 & 6 & 575 & 16 & 574 & 15 & 0,95 & 0 & 0,0008 & 163,52 & 11,50 & 20,46 \\
\hline $\mathrm{Zr}-25(\mathrm{~T}-16)$ & 0,76110 & 2,98 & 0,09347 & 0,88 & \begin{tabular}{|l|}
0,29 \\
\end{tabular} & 0,05905 & 2,85 & 576 & 5 & 575 & 17 & 569 & 16 & 0,54 & -2 & 0,0012 & 77,26 & 9,50 & 17,06 \\
\hline $\mathrm{Zr}-26(\mathrm{~T}-16)$ & 0,74043 & 3,64 & 0,09115 & 1,35 & 0,37 & 0,05891 & 3,38 & 562 & 8 & 563 & 20 & 564 & 19 & 1,42 & 0 & 0,0021 & 99,19 & 4,65 & 10,67 \\
\hline $\mathrm{Zr}-27(\mathrm{~T}-16)$ & 0,74052 & 3,88 & 0,09176 & 1,30 & 0,33 & 0,05853 & 3,66 & 566 & 7 & 563 & 22 & 550 & 20 & 0,93 & -4 & 0,0041 & 50,52 & 3,61 & 6,71 \\
\hline $\mathrm{Zr}-28(\mathrm{~T}-16)$ & 0,77839 & 3,79 & 0,09539 & 1,40 & 0,37 & 0,05918 & 3,52 & 587 & 8 & 585 & 22 & 574 & 20 & 1,40 & -3 & 0,0038 & 138,43 & 6,60 & 13,40 \\
\hline Zr-29 (T-16) & 0,74674 & 3,13 & 0 & 0,88 & 0,28 & 0,05922 & 3,01 & 564 & 5 & 566 & 18 & 575 & 17 & 0,33 & 2 & 0,0020 & 43,09 & 8,79 & 15,08 \\
\hline $\mathrm{Zr}-30(\mathrm{~T}-16)$ & 0,76497 & 3,81 & 0 & 1,53 & 0,40 & 0,05936 & 3,49 & 576 & 9 & 577 & 22 & 580 & 20 & 0,66 & 1 & 0,0010 & 54,65 & 83,95 & 9,57 \\
\hline Zr-31 (T-16) & 0,72122 & 2,99 & 0,08923 & 1,35 & 0,45 & 0,05862 & 2,66 & 551 & 7 & 551 & 16 & 553 & 15 & 0,67 & 0 & 0,0008 & 52,85 & 78,92 & 9,16 \\
\hline Zr-32 (T-16) & 0,79736 & 2,40 & 0,09678 & 1,16 & 0,49 & 0,05975 & 2,10 & 596 & 7 & 595 & 14 & 595 & 12 & 0,52 & 0 & 0,0010 & 45,54 & 87,47 & 10,02 \\
\hline $\mathrm{Zr}-33(\mathrm{~T}-16)$ & 0,76599 & 2,78 & 0,09366 & 1,07 & 0,38 & 0,05931 & 2,56 & 577 & 6 & 577 & 16 & 579 & 15 & 1,29 & 0 & 0,0008 & 149,60 & 116,95 & 16,27 \\
\hline
\end{tabular}

1. Amostras e padrões corrigidos após lacunas $\mathrm{Pb}$ e $\mathrm{Hg}$.

2. ${ }^{207} \mathrm{~Pb} / 206 \mathrm{~Pb}$ and ${ }^{206} \mathrm{~Pb}{ }^{238} \mathrm{U}$ foram corrigidos após a presença do $\mathrm{Pb}$ comum. $\mathrm{Pb}$ comum assumindo ${ }^{206} \mathrm{~Pb} \mathrm{p}^{238} \mathrm{U}{ }^{207} \mathrm{~Pb}{ }^{235} \mathrm{U}$ como idade concordante

3. ${ }^{235} \mathrm{U}=1 / 137.88 * \mathrm{U}$ total

4. Padrão GJ-1

5. $\mathrm{Th} / \mathrm{U}={ }^{232} \mathrm{Th} /{ }^{238} \mathrm{U} * 0.992743$

6. todos os eros na tabela foram calculados para 1 sigma (\% para razões isotópicas, absoluto para idades) 

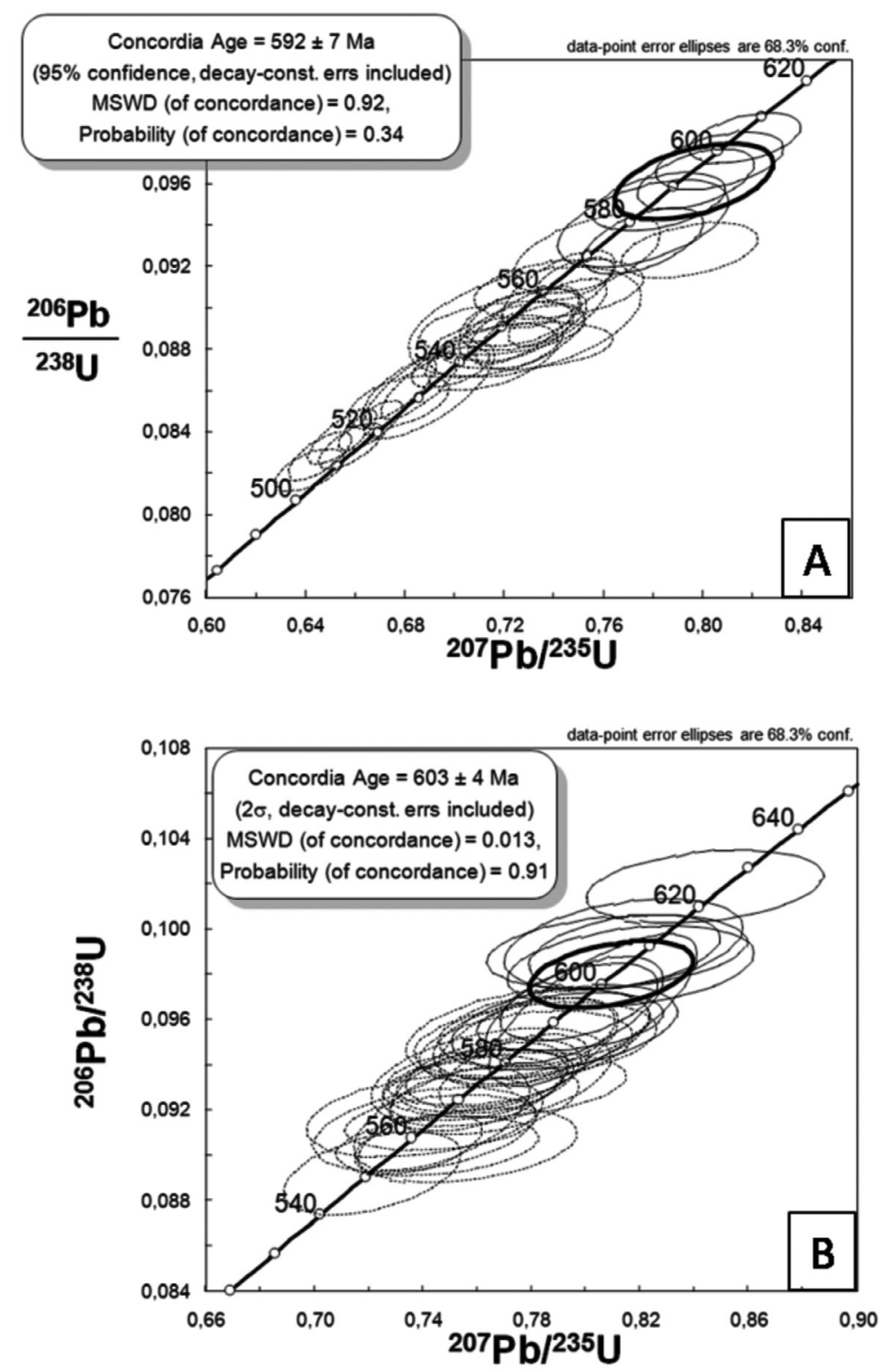

Figura 10 - Diagrama concórdia, amostras TJ-46 (A) e T-16 (B). Idade concórdia representada pela elipse destacada em linha grossa. As elipses tracejadas não foram incluídas no calculo da idade.

processos de perda de $\mathrm{Pb}$ evidenciados pelos cristais de zircão analisados seriam primeiramente devidos ao metamorfismo granulítico, no contexto do metamorfismo regional que afetou o orógeno e cujo pico tem sido datado em ca. $585 \mathrm{Ma}$ (Pedrosa-Soares et al. 2001, 2008, Heilbron \& Machado, 2003, Heilbron et al. 2004, Silva et al. 2005). Eventos termais e de granitogênese subseqüentes, que se estenderam até $c a .500 \mathrm{Ma}$, poderiam explicar a perda de $\mathrm{Pb}$ adicional e as idades mais jovens reveladas por parte dos grãos.

Dados Sm-Nd Duas amostras da Suíte Divino foram analisadas para Sm-Nd no Laboratório de Geocronologia da Universidade de Brasília (Tab.5), conforme metodologia descrita por Gioia \& Pimentel (2000). As amostras eram de composição intermediária (TJ-46) e básica (T-
Tabela 5 - Resultados analíticos $\mathrm{Sm}-\mathrm{Nd}$.

\begin{tabular}{c|c|c|c|c|c|c}
\hline Amostra & $\mathrm{Sm}(\mathrm{ppm})$ & $\mathrm{Nd}(\mathrm{ppm})$ & ${ }^{147} \mathrm{Sm} /{ }^{144} \mathrm{Nd}$ & ${ }^{143} \mathrm{Nd} /{ }^{144} \mathrm{Nd} \pm 2 \mathrm{SE}$ & $\varepsilon(\mathrm{o})$ & $\begin{array}{c}\mathrm{T}_{\mathrm{DM}} \\
(\mathrm{Ga})\end{array}$ \\
\hline $\mathrm{TJ}-46$ & 6,768 & 32,700 & 0,1251 & $0,511821+/-11$ & $-10,6$ & 2,09 \\
\hline $\mathrm{T}-7$ & 24,107 & 122,566 & 0,1189 & $0,511815+/-4$ & $-10,2$ & 1,96 \\
\hline
\end{tabular}

7). Os valores fortemente negativos de $\varepsilon_{\mathrm{Ndt}}(\mathrm{t}=600 \mathrm{Ma})$, em torno de -10 , indicam elevada contribuição crustal na geração dos magmas precursores das rochas charnockíticas. A idade paleoproterozóica desta fonte crustal é 
sugerida pelas idades-modelo TDM por volta de 2,0 Ga. INTERPRETAÇÃO PETROLÓGICA E GEOTECTÔNICA DA SUÍTE DIVINO A intrusão da Suíte Divino em $c a$. 600 Ma enquadra-se no intervalo de tempo (630-582 Ma) atribuído ao estágio pré-colisional do Orógeno Araçuaí (Pedrosa-Soares et al. 2001, 2008, Silva et al. 2005).

Estas idades são, portanto, compatíveis com as idades de cristalização magmática de outras suítes plutônicas cálcio-alcalinas do Orógeno Araçuaí, tais como Galiléia (594 \pm 6 Ma; Nalini et al. 2000) e Teófilo Otoni (586 Ma; Whittington et al. 2001, Martins et al. 2004), e do vulcanismo dacítico (ca. $585 \mathrm{Ma}$ ) associado ao Grupo Rio Doce (Vieira 2007).

A Suíte Divino pode ser classificada como uma suíte cálcio-alcalina expandida, e sua assinatura geoquímica guarda marcante semelhança com aquela da Suíte Galiléia, como pode ser observado na figura 11. Os valores de $\varepsilon_{\text {Ndt }}$ são igualmente semelhantes, em torno de -10 para a Suíte Divino e variando entre $-8,3$ e -9,3 para a Suíte Galiléia (Nalini et al. 2000). Estes valores negativos são esperados em rochas de arco magmático de margem continental e marcantes no caso do Orógeno Araçuaí, como demonstram também os plutons tonalíticos da região de Teófilo Otoni cujos valores de $\varepsilon_{\mathrm{Ndt}}$ variam entre -8 e -10 (Martins et al. 2004). A assinatura de $\mathrm{Nd}$ indica a contribuição de crosta continental antiga para este magmatismo que, no caso da Suíte Divino, deve ser representada pelo Complexo Juiz de Fora de idade paleoproterozóica. Uma comparação entre as assinaturas geoquímicas das duas unidades (Fig. 12, $13 \mathrm{e}$ 14) revela o seguinte (os dados para o Complexo Juiz de Fora foram compilados de Duarte et al. (1997) e Noce et

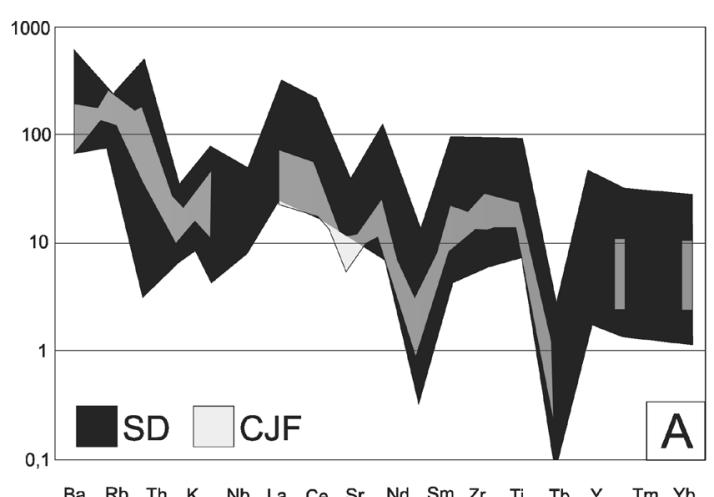

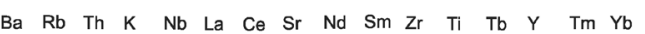

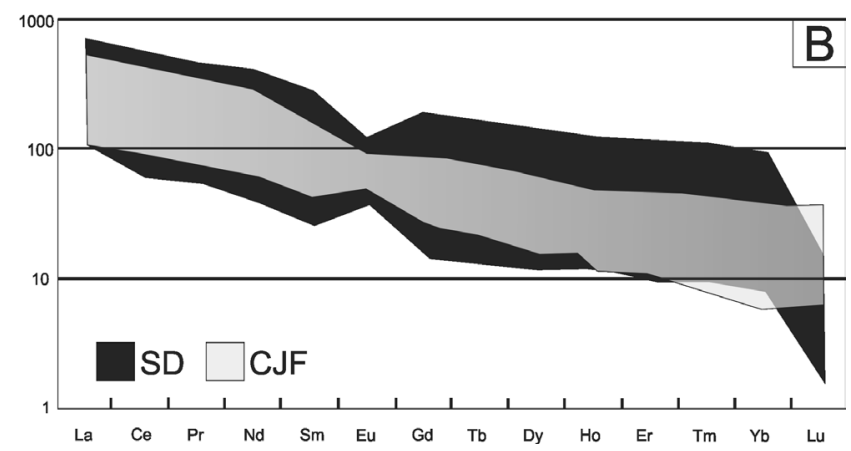

Figura 11 - (A) Padrão de elementos terras raras normalizados para condrito (Boynton 1984). (B) Diagramas de variação multi-elementar normalizados para o manto primitivo (Taylor \& McLennan 1985). SD Suite Divino e $S G$ - Suite Galiléia (dados de Nalini et al. 2000).

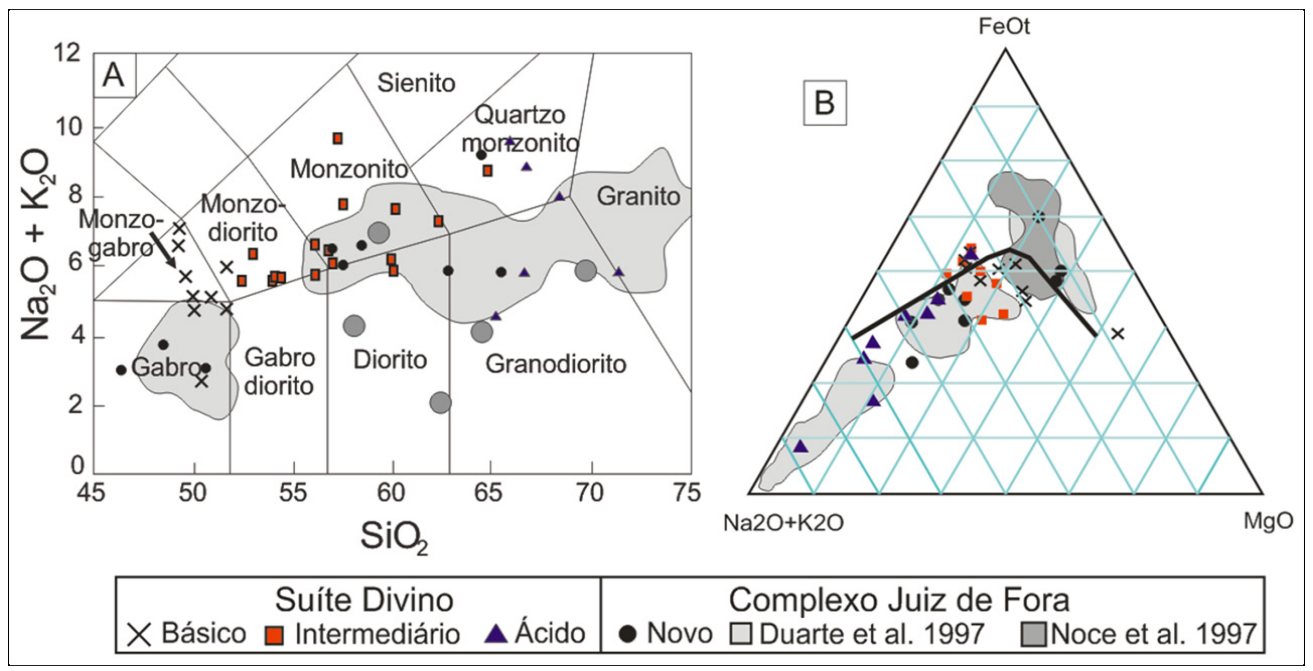

Figura 12 - Diagramas comparativos entre a Suite Divino e o Complexo Juiz de Fora (dados de Noce et al. 2007b, Duarte et al. 1997 e dados inéditos) segundo sua composição química. (A) Diagrama TAS (Wilson 1989). (B) Diagrama AFM (Jensen 1976). Símbolos iguais aos da figura 3, círculos pretos representam dados de Novo para o Complexo Juiz de Fora, nuvens e circulos cinza claro representam dados de Duarte et al. 1997 para o Complexo Juiz de Fora e nuvens cinza escuro representam dados de Noce et al. 2006. 


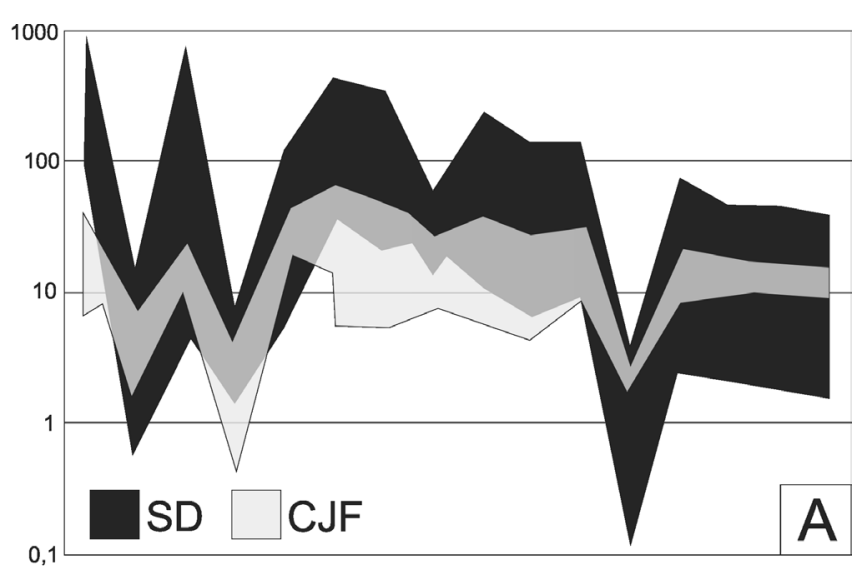

$\begin{array}{lllllllllllllllllll}\mathrm{Ba} & \mathrm{Rb} & \mathrm{Th} & \mathrm{K} & \mathrm{Nb} & \mathrm{La} & \mathrm{Ce} & \mathrm{Sr} & \mathrm{Nd} & \mathrm{Sm} & \mathrm{Zr} & \mathrm{Ti} & \mathrm{Tb} & \mathrm{Y} & \mathrm{Tm} & \mathrm{Yb}\end{array}$

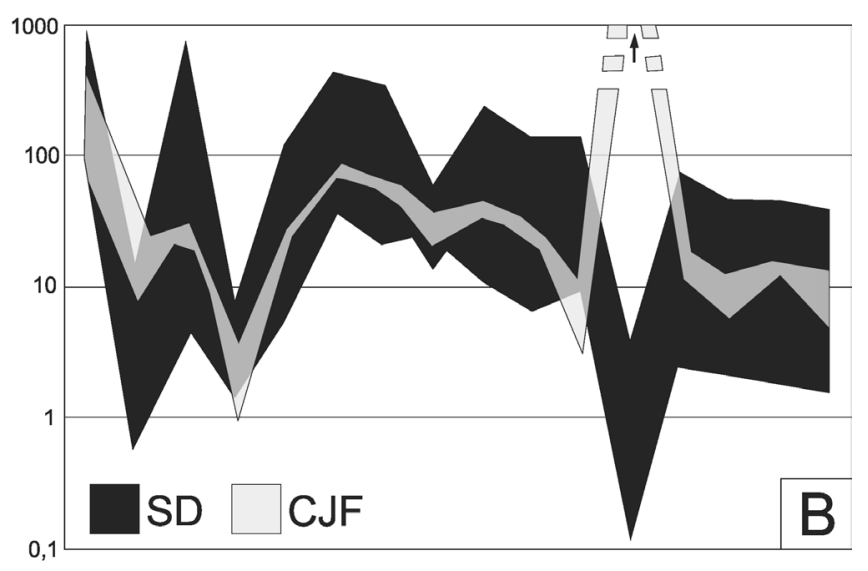

$\begin{array}{llllllllllllllll}\mathrm{Ba} & \mathrm{Rb} & \mathrm{Th} & \mathrm{K} & \mathrm{Nb} & \mathrm{La} & \mathrm{Ce} & \mathrm{Sr} & \mathrm{Nd} & \mathrm{Sm} & \mathrm{Zr} & \mathrm{Ti} & \mathrm{Tb} & \mathrm{Y} & \mathrm{Tm} & \mathrm{Yb}\end{array}$

Figura 13 - Diagramas de variação multi-elementar (normalizados para o manto primitivo; Taylor \& McLennan 1985) para amostras da Suite Divino, comparadas com os granulitos básicos (A) e gnaisses enderbiticos (B) do Complexo Juiz de Fora (dados de Duarte et al. 1997). SD - Suite Divino e CJF - Complexo Juiz de Fora.

al. (2007a), além de dados inéditos exibidos na tabela 1):

1. Ambas as unidades possuem caráter metaluminoso. A Suíte Divino é enriquecida em álcalis e exibe distribuição uniforme de termos ácidos, intermediários e básicos, definindo assinatura de suíte cálcio-alcalina expandida. As amostras do Complexo Juiz de Fora se concentram em duas populações distintas, uma granítica a dioríticamonzonítica e outra gabróica, resultando em uma dupla assinatura, cálcio-alcalina e toleiítica (Fig. 12a e 12b);

2. A Suíte Divino apresenta pequeno enriquecimento em elementos incompatíveis e intermediários relativamente ao Complexo Juiz de Fora, e maior espalhamento das curvas de elementos terras raras. Entretanto, em termos gerais as envoltórias de distribuição de elementos traço e terras raras são similares, excluindo-se as rochas básicas toleiíticas do Complexo Juiz de Fora (Figs. 13 e 14).

As semelhanças registradas refletem o caráter cálcio-alcalino das duas unidades, ressaltando-se o fato da Suíte Divino não incluir o componente tolei-
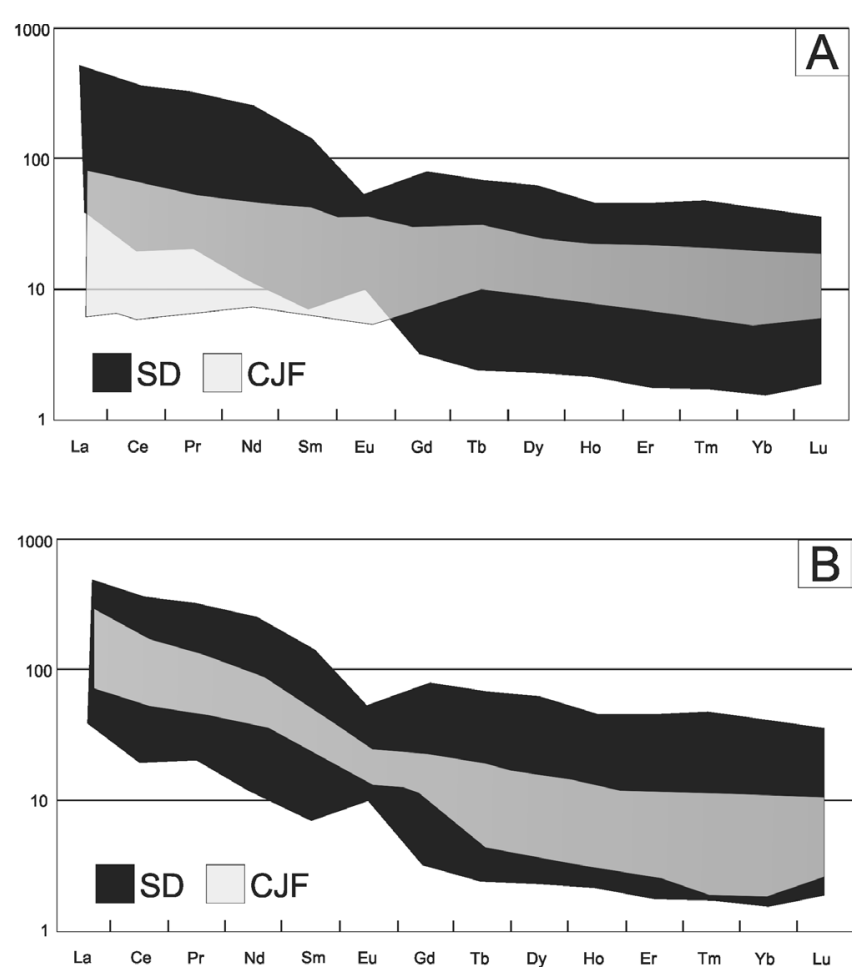

Figura 14 - Padrões de elementos terras raras (normalizados para condrito; Boynton 1984) para amostras da Suite Divino, comparadas com os granulitos básicos (A) e gnaisses enderbíticos (B) do Complexo Juiz de Fora (dados de Duarte et al. 1997). SD - Suite Divino e CJF - Complexo Juiz de Fora.

ítico. Por sua vez, esta apresenta enriquecimento em $\mathrm{K}$ (em vez de $\mathrm{Na}$ ) e em diversos elementos traço, o que favorece a hipótese da contribuição das rochas do Complexo Juiz de Fora em sua gênese. Entretanto, dificilmente este seria uma fonte única, visto a assinatura cálcio-alcalina expandida da Suíte Divino sugerir também a contribuição de fontes mantélicas. É importante ressaltar que o Complexo Juiz de Fora é essencialmente de composição enderbítica (i.e., tonalítica) e seus mobilizados migmatíticos são charnockíticos (graníticos) a opdalíticos (granodioríticos).

CONCLUSÃO A Suíte Divino constitui uma unidade plutônica caracterizada pela primeira vez na região de fronteira entre os orógenos Araçuaí e Ribeira. Possui as características de uma suíte cálcioalcalina expandida, originada em arco magmático de margem continental ativa, com significativo envolvimento de fusões derivadas da crosta profunda de idade paleoproterozóica, representada pelo Complexo Juiz de Fora.

A continuidade do arco magmático pré-colisional do Orógeno Araçuaí nesta região já havia sido sugerida pela descrição do corpo tonalítico de Manhuaçu (ca. 597 Ma, Noce et al. 2006) e do Batólito de Muriaé (620-590 Ma, Figueiredo 2009; vide mapa 
da figura 1). Considera-se que a Suíte Divino representa a exposição da raiz granulítica deste arco. $\mathrm{O}$ posicionamento dos corpos sempre a leste da Falha de Abre Campo reforça a identificação desta estrutura como uma zona de sutura basiliana.
Agradecimentos Os autores agradecem ao CNPq (auxílios à pesquisa e bolsas de produtividade em pesquisa), FAPEMIG e CAPES (bolsa de mestrado de T. Novo) e ao Programa Geologia do Brasil-Contrato CPRM-UFMG.

\section{Referências}

Almeida F.F.M., Brito-Neves B.B., Carneiro C.D.R. 2000. The origin and evolution of the South American platform. Earth Science Review, 50:77-111.

Batchelor R.A. \& Bowden P. 1985. Petrogenetic interpretation of graniitoid rock series using multicationic parameters. Chemical Geology, 48:43-55.

Boynton W.V. 1984. Cosmochemistry of the rare earth elements: meteorite studies. In: Henderson P. (ed.) Rare earth element Geochemistry. Developments in geochemistry. Amsterdam, Elsevier, p.63-114.

Brey G.P. \& Köhler T. 1990. Geothermobarometry in fourphase lherzolites: II. New thermobarometers and practical assessment of existing thermobarometry. Journal of Petrology, 31:1352-1378.

Brito-Neves B.B., Campos-Neto M., Fuck R.A. 1999. From Rodinia to Western Gondwana: An approach to the Brasiliano- Pan African cycle and orogenic collage. Episodes, 22:155-199.

Chappell B.W. \& White A.J.R. 2001. Two contrasting granite types: 25 years later. Australian Journal of Earth Sciences 48:489-499.

Cunningham D., Alkmim F.F., Marshak S. 1998. A structural transect across the coastal mobile belt in the Brazilian Highlands (latitude $20^{\circ} \mathrm{S}$ ): the roots of a Precambrian transpressional orogen. Precambrian Research, 92:251275.

Duarte B.P., Figueiredo M.C.H., Campos-Neto M., Heilbron M. 1997. Geochemistry of the granulite facies orthogneisses of Juiz de Fora Complex, central segment of Ribeira Belt, southeastern Brazil. Revista Brasileira de Geociências, 27:67-82.

Duarte B.P., Heilbron M., Campos-Neto M. 2000. Granulite/ charnockite from the Juiz de Fora Domain, central segment of the Brasiliano Ribeira Belt. Revista Brasileira de Geociências, 30:358-362.

Duarte B.P., Heilbron M., Campos Neto M.C., Porto Jr.R. 1999. The Garnet Charnockite Plutonic Body of the Juiz de Fora Region, Central Segment of the Pan-AfricanBrasiliano Ribeira Belt, Southeastern Brazil. In: SBG/ BA, Simp. Nac. de Estudos Tectonicos, 7, Boletim de Resumos Expandidos, 2:56-57.

Figueiredo C.M. 2009. O Arco Magmático Brasiliano na conexão entre os orógenos Araçuaí e Ribeira. Dissertação de Mestrado, Instituto de Geociências, Universidade Federal de Minas Gerais, 104 p.

Frost B.R. \& Frost C.D. 2008. On charnockites. Gondwana Research, 12:30-44.

Gioia S.M.C.L., Pimentel M.M. 2000. The Sm-Nd isotopic method in the geochronology laboratory of the University of Brasília. Anais da Academia Brasília de Ciências, 72:219-245.
Heilbron M. \& Machado N. 2003. Timing of terrane accretion in the Neoproterozoic-Eopaleozoic Ribeira orogen (SE Brazil). Precambrian Research, 125:87-112.

Heilbron M., Pedrosa-Soares A.C., Campos-Neto M., Silva L.C., Trouw R., Janasi V.A. 2004. Província Mantiqueira. In: Mantesso-Neto V.M., Bartorelli A., Carneiro C.D.R., Brito-Neves B.B. (eds.). Geologia do Continente SulAmericano. São Paulo, Editora Beca, p. 203-234.

Jensen L.S. 1976. A new cation plot for classifying subalkaline volcanic rocks. Ontario Division of Mines, Misc., Paper 66.

Le Maitre R.W. 1989. A Classification of Igneous Rocks and Glossary of Therms. Oxford, Blackwell, 193 p.

Ludwig K.R., 2001. Users Manual for Isoplot/Ex version 2.47. A geochronological toolkit for Microsoft Excel. Berkeley Geochronology Center Special Publication 1a, $55 \mathrm{p}$.

Martin H., Peucat J.J., Sabaté P., Cunha J.C., 1997. Crustal evolution in the early Archaean of South America: example of the Sete Voltas Massif, Bahia State Brazil. Precambrian Research, 82:35-62.

Martins V.T.S., Teixeira W., Noce C.M., Pedrosa-Soares A.C. 2004. Sr and Nd characteristics of Brasiliano/Pan-African granitoid plutons of the Araçuaí Orogen, Southeastern Brazil: tectonic implications. Gondwana Research, 7:75-89.

Nalini H.A., Bilal E., Paquette J.L., Pin C., Machado R. 2000. Geochronologie $\mathrm{U}-\mathrm{Pb}$ et géochimie isotopique $\mathrm{Sr}-\mathrm{Nd}$ des granitoïdes néoprotérozoiques des suites Galileia et Urucum, vallée du Rio Doce, Sud-Est du Brésil. Compte Rendu Academie Science Paris, 331:459-466.

Noce C.M., Costa A.G., Piuzana D., Vieira V.S., Carvalho C. 2006. Geologia da Folha Manhuaçu 1:100.000. Rio de Janeiro, CPRM-Serviço Geológico do Brasil, UFMGPrograma Geologia do Brasil.

Noce C.M., Pedrosa-Soares A.C., Silva L.C., Alkmim F.F. 2007a. O Embasamento Arqueano e Paleoproterozóico do Orógeno Araçuaí. Geonomos, 15:17-23.

Noce C.M., Pedrosa-Soares A.C., Silva L.C., Armstrong R., Piuzana D. 2007b. Evolution of polyciclic basement complexes in the Araçuaí Orogen, based on U-Pb SHRIMP data: Implications for Brazil-Africa links in Paleoproterozoic time. Precambrian Research. 159:60 -78.

Pearce J.A., 1996. Sources and settings of granitic rocks. Episodes, 19:120-125.

Pearce J., Harris N., Tindle A. 1984. Trace element discrimination diagrams for the tectonic interpretation of granitic rocks. Journal of Petrology, 259:956-983.

Pedrosa-Soares A.C., Noce C.M., Wiedemann C.M., Pinto, C.P. 2001. The Araçuaí-West Congo orogen in Brazil: An overview of a confined orogen formed during Gond- 
wanland assembly. Precambrian Research, 110:307-323.

Pedrosa-Soares A.C., Alkmim F.F., Tack L., Noce C.M., Babinski M., Silva L.C., Martins-Neto M.A. 2008. Similarities and differences between the Brazilian and African counterparts of the Neoproterozoic Araçuaí-West-Congo orogen. In: Geological Society, London, Special Publications, 294:153-172.

Peres G.G., Alkmim F.F., Jordt-Evangelista H. 2004. The southern Araçuaí belt and the Dom Silvério Group: geologic architecture and tectonic significance. Anais da Academia Brasileira de Ciências, 76:771-790.

Pons M.J., Franchini M.B., López Escobar L. 2007. Los cuerpos ígneos neógenos del Cerro de las Minas $\left(35,3^{\circ} \mathrm{s}\right.$ - 69,9 $9^{\circ}$ ), cordillera principal de los Andes, SO de mendoza: geología, petrografía y geoquímica. Revista de la Asociación Geológica Argentina, 62(2):267- 282.

Rickwood P.C. 1989. Boundary lines within petrologic diagrams which use oxides of major and minor elements. Lithos, 22:247-263.

Rogers J.J.W. \& Adams J.A.S. 1978. Th Abundances in common igneous rocks. In: Wedepohl K.H. (ed.) Handbook of Geochemistry. Berlin, Springer-Verlag, p.90-E-1 - 90E-12.

Rollinson H. (ed.) 1993. Using geochemical data: evaluation, presentation, interpretation. London, Longman Scientific \& Technical, $352 \mathrm{p}$.

Rudnick R.L., Mclennan S.M., Taylor S.R. 1985. Large ion lithophile elements in rocks from high-pressure granulite facies terrains. Geochemica et Cosmochimica Acta, 49:1645-1655.

Shand S.J. 1947. Eruptive Rocks. 3.ed, New York, Hafner Publishing Company, 488 p.

Silva L.C., McNaughton N.J., Armstrong R., Hartmann L., Fletcher I. 2005. The Neoproterozoic Mantiqueira Prov- ince and its African connections. Precambrian Research, 136:203-240.

Simon E., Jackson S. E., Pearson N. J., Griffin W.L., Belousova E.A. 2004. The application of laser ablation-inductively coupled plasma-mass spectrometry to in situ U-Pb zircon geochronology. Chemical Geology, 211:47-69

Sun S.S. 1980. Lead isotopic study of young volcanic rocks from mid-ocean ridges, ocean islands and island arcs. Philosophical Transactions of the Royal Society, 297:409445.

Taylor S.R. \& McLennan S.M. (eds.) 1985. The Continental Crust; Its composition and evolution; an examination of the geochemical record preserved in sedimentary rocks. Oxford, Blackwell, 312 p.

Valladares C., Duarte B.P., Heilbron M., Ragatky D. 2000. Tectono-magmatic evolution of the Occidental terrane and the Paraiba do Sul Klippe of the Neoproterozoic Ribeira Orogenic belt, southeastern Brazil. Revista Brasileira de Geociências, 30:1-6.

Vieira V.S. 2007. Significado do Grupo Rio Doce no Contexto do Orógeno Araçuaí. Tese de Doutoramento, Instituto de Geociências, Universidade Federal de Minas Gerais, 123 p.

Wilson M. 1989. Igneous Petrogenesis. London, Unwin Hyman, $470 \mathrm{p}$.

Whittington A.G., Connelly J., Pedrosa-Soares A.C., Marshak S., Alkmim F.F. 2001. Collapse and melting in a confined orogenic belt: preliminary results from the Neoproterozoic Araçuaí belt of eastern Brazil. In: AGU Fall Meeteing, American Geophysical Union, Abstract, $n^{\circ}$ T32B-0895, 82:1181-1182.

Manuscrito ID 17128

Submetido em 26 de março de 2010 Aceito em 30 de novembro de 2010 